\title{
Microstructural and physiological responses to cadmium stress under different nitrogen levels in Populus cathayana females and males
}

\author{
Liu, Miao
}

2020-01

Liu , M , Bi , J , Liu , X , Kang , J , Korpelainen , H , Niinemets , U \& Li , C 2020 , '

Microstructural and physiological responses to cadmium stress under different nitrogen levels in Populus cathayana females and males ' , Tree Physiology, vol. 40 , no. 1 , pp. 30-45 . https://doi.org/10.1093/treephys/tpz115

http://hdl.handle.net/10138/323968

https://doi.org/10.1093/treephys/tpz115

unspecified

acceptedVersion

Downloaded from Helda, University of Helsinki institutional repository.

This is an electronic reprint of the original article.

This reprint may differ from the original in pagination and typographic detail.

Please cite the original version. 
3 Microstructural and physiological responses to cadmium stress under different 0

(1)

\section{nitrogen levels in Populus cathayana females and males}
Miao Liu ${ }^{1}$, Jingwen $\mathrm{Bi}^{1}$, Xiucheng Liu ${ }^{1}$, Jieyu Kang ${ }^{1}$, Helena Korpelainen $^{2}$, Ülo Niinemets ${ }^{3,4,5}$, Chunyang Li ${ }^{1, *}$

${ }^{1}$ College of Life and Environmental Sciences, Hangzhou Normal University, Hangzhou 310036, China

${ }^{2}$ Department of Agricultural Sciences, Viikki Plant Science Centre, University of Helsinki, P.O. Box 27, FI-00014, Finland

${ }^{3}$ Institute of Agricultural and Environmental Sciences, Estonian University of Life Sciences, Kreutzwaldi 1, 51006 Tartu, Estonia

${ }^{4}$ Estonian Academy of Sciences, Kohtu 6, 10130 Tallinn, Estonia

${ }^{5}$ School of Forestry and Bio-Technology, Zhejiang Agriculture \& Forestry University, Hangzhou, Zhejiang, 311300, China

* Corresponding author: Chunyang Li, E-mail address: licy@hznu.edu.cn

Head title: Sexual differences in responses to $\mathrm{Cd}$ and $\mathrm{N}$ deficiency in poplar 
Abstract Although an increasing attention has been paid on the relationships between heavy metal and nitrogen availability, the mechanism underlying adaptation to Cd stress in dioecious plants has been largely overlooked. This study examined $\mathrm{Cd}$ accumulation, translocation and allocation among tissues and cellular compartments in Populus cathayana females and males. Both leaf $\mathrm{Cd}$ accumulation and root-to-shoot $\mathrm{Cd}$ translocation were significantly greater in females than in males under a normal $\mathrm{N}$ supply, but they were reduced in females and enhanced in males under $\mathrm{N}$ deficiency. The genes related to Cd uptake and translocation, HMA2, YSL2 and ZIP2, were strongly induced by $\mathrm{Cd}$ stress in female roots and in males under a normal $\mathrm{N}$ supply. Cd largely accumulated in the leaf blades of females and in the leaf veins of males under a normal $\mathrm{N}$ supply, while the contrary was true under $\mathrm{N}$ deficiency. Furthermore, Cd was mainly distributed in the leaf epidermis and spongy tissues of males, and in the leaf palisade tissues of females. $\mathrm{N}$ deficiency increased Cd allocation to the spongy tissues of female leaves and to the palisade tissues of males. In roots, $\mathrm{Cd}$ was preferentially distributed to the epidermis and cortices in both sexes, and also to the vascular tissues of females under a normal $\mathrm{N}$ supply but not under $\mathrm{N}$ deficiency. These results suggested that males possess better $\mathrm{Cd}$ tolerance compared to females, even under $\mathrm{N}$ deficiency, which is associated with their reduced root-to-shoot $\mathrm{Cd}$ translocation, specific $\mathrm{Cd}$ distribution in organic and/or cellular compartments, and enhanced antioxidation and ion homeostasis. Our study also provides new insights into engineering woody plants for phytoremediation. 
Keywords: dioecy, sexual differences, Cd distribution, nitrogen level, sequestration.

\section{Introduction}

Cadmium (Cd) is a nonessential and highly toxic element for plants. Cd is not only harmful to plant growth and metabolism but it also threatens human health, as large amounts of Cd may enter the food chain (Godt et al. 2006; Li et al, 2018). Phytoremediation by plants has been proposed to be an effective biotechnological strategy to remediate Cd-contaminated soils (Castagna et al. 2013, Li et al. 2018). Plants have evolved a series of strategies for $\mathrm{Cd}$ detoxification and tolerance. $\mathrm{Cd}$ could be sequestrated into cell walls and/or vacuoles, and it could induce antioxidant synthesis to alleviate oxidative stress (Peng et al. 2017, Zhang et al. 2018). Different plant species showhave different tolerances to $\mathrm{Cd}$ and employ different mechanisms to reduce $\mathrm{Cd}$ toxicity, but there can be different detoxification mechanism engaged even by the same species among different genotypes (Meyer et al. 2015, 2016).

Poplars have been suggested as promising candidates for remediating heavy metalpolluted soils due to their high growth rates and low impact on the food chain (Iori et al. 2016). Thus, both from the wood production and phytoremediation point of view it is important to improve poplars' growth and tolerance under Cd stress. The use of nitrogen fertilizers has been recently suggested to be one of the most important practices to alleviate Cd toxicity in plants (Chen et al., 2011; Liu et al., 2017), while Cd toxicity 
affects nitrogen absorption and metabolism (Erdal \& Turk, 2016). Cd inhibits $\mathrm{NO}_{3}{ }^{-}$ uptake and impairs nitrate homeostasis, resulting in a decrease in nitrate transport from roots to shoots (Mao et al. 2014). Some enzymes related to nitrogen metabolism, such as nitrate reductase, glutathione synthase and glutamate synthetase, are also affected by Cd stress (Sharma et al. 2010, Erdal \& Turk, 2016). In turn, some nitrogen metabolites, such as proline, glutathione (GSH) and phytochelatins (PCs), facilitate $\mathrm{Cd}$ detoxification in plants (Sharma \& Dietz, 2006). Therefore, changes in the nitrogen status of plants may affect the stress caused by $\mathrm{Cd}$.

Previous studies have suggested that responses of nitrogen metabolism to $\mathrm{Cd}$ stress vary among plant species, even among genotypes within the same species (Liao et al. 2019), as observed, e.g., in Medicago sativa (Yang et al. 2019). Furthermore, recent studies have shown that dioecious plants, e.g., Populus species, display sexual differences in defense responses to abiotic stress, including Cd toxicity, males usually displaying a better tolerance compared to females ( $\mathrm{Li}$ et al. 2016, Chen et al. 2017), but the mechanisms causing sexual differences in Cd tolerance are poorly known. We have previously found that P. yunnanensis females are more sensitive to Cd stress than males, but $\mathrm{N}$ deposition could mitigate $\mathrm{Cd}$ toxicity and decrease sexual differences (Chen et al., 2011). However, sex-specific responses to combinations of $\mathrm{Cd}$ and $\mathrm{N}$ availability and underlying mechanisms have not been elucidated in P. cathayana. Therefore, we investigated physiological and molecular mechanisms related to nitrogen status and cadmium toxicity in $P$. cathayana males and females in order to reveal potential sex- 
specific response patterns and to test the efficacy of enhanced $\mathrm{N}$ availability to alleviate Cd stress.

\section{Materials and Methods}

Plant material and growth conditions

Cuttings of $P$. cathayana females and males were collected from 60 different trees sampled in 15 populations, containing 30 females and 30 males, in the riparian and valley flat habitats of the Qinghai Province, China. Annual temperature, mean annual rainfall and annual solar radiation in the area are $6.9{ }^{\circ} \mathrm{C}$ (maximum $38^{\circ} \mathrm{C}$, minimum $20^{\circ} \mathrm{C}$ ), $335 \mathrm{~mm}$ and $4500 \mathrm{MJ} \mathrm{m}^{-2}$, respectively (Zhao et al., 2009). Cuttings were rooted as described by Chen et al. (2015). The experimental design was with three factors (sex, $\mathrm{N}$ and $\mathrm{Cd}$ ), i.e. two sexes (females, males), two Cd regimes $(-\mathrm{Cd},+\mathrm{Cd})$ and two $\mathrm{N}$ levels ( $\mathrm{N}$ deficiency, sufficient $\mathrm{N}$ ). The seedlings were grown in a greenhouse at the Hangzhou Normal University. After one month, uniform cuttings were chosen and transplanted into plastic pots with a $10 \mathrm{~kg}$ mixture of sand, vermiculite and perlite $(1: 1: 1)$. Every three days, $100 \mathrm{ml}$ of nutrient solution and $100 \mathrm{ml}$ of sterile distilled water were used for irrigation. The composition of the nutrient solution was as follows $(\mu \mathrm{M}): 500 \mu \mathrm{M}$ $\mathrm{KCl}, 900 \mu \mathrm{M} \mathrm{CaCl}_{2}, 300 \mu \mathrm{M} \mathrm{MgSO}_{4}, 0.1 \mu \mathrm{M} \mathrm{CuSO}_{4}, 0.5 \mu \mathrm{M} \mathrm{MnSO}_{4}, 600 \mu \mathrm{M} \mathrm{KH}_{2} \mathrm{PO}_{4}$, $42 \mu \mathrm{M} \mathrm{K}_{2} \mathrm{HPO}_{4}, 2000 \mu \mathrm{M} \mathrm{NH}_{4} \mathrm{NO}_{3}, 25 \mu \mathrm{M}$ Fe-EDTA, $10 \mu \mathrm{M} \mathrm{H}_{3} \mathrm{BO}_{3}, 0.5 \mu \mathrm{M} \mathrm{ZnSO}_{4}$, and $0.1 \mu \mathrm{M}\left(\mathrm{NH}_{4}\right)_{6} \mathrm{Mo}_{7} \mathrm{O}_{24}$. The $\mathrm{pH}$ of the solution was adjusted to 6.0 using $\mathrm{HCl}$. After 
111

112

113

114

115

the seedlings had been growing in sandy pots for $30 \mathrm{~d}$, uniform cuttings were subjected to $\mathrm{Cd}$ and $\mathrm{N}$ treatments for $120 \mathrm{~d}$. In the $\mathrm{N}$ treatment, the seedlings were irrigated with a complete $2000 \mu \mathrm{M} \mathrm{NH} \mathrm{NO}_{3}(+\mathrm{N}+\mathrm{Cd})$ or $\mathrm{NH}_{4} \mathrm{NO}_{3}$-free nutrient solution $(-\mathrm{N}+\mathrm{Cd})$, and the final $\mathrm{NH}_{4} \mathrm{NO}_{3}$ level reached $200 \mathrm{mg} \mathrm{N} \mathrm{kg}^{-1}$ soil. In the $\mathrm{Cd}$ treatment, $\mathrm{CdCl}_{2}$. $2.5 \mathrm{H}_{2} \mathrm{O}$ of $100 \mu \mathrm{M}$ was applied to the sandy pots every day during the first $40 \mathrm{~d}$, and the final Cd level reached $50 \mathrm{mg} \mathrm{CdCl}_{2} \cdot 2.5 \mathrm{H}_{2} \mathrm{O} \mathrm{kg}{ }^{-1}$ dry soil.

\section{Growth measurements}

The plants were collected after the end of the experiments. Samples of roots, leaves and stems were first oven-dried at $105{ }^{\circ} \mathrm{C}$ for $1 \mathrm{~h}$ and then dried at $70{ }^{\circ} \mathrm{C}$ until a constant mass was reached, after which the dry mass (DM) was estimated.

\section{Gas exchange measurements and estimation of photosynthetic pigments}

The fourth fully expanded leaves were chosen to measure the net photosynthesis rate, stomatal conductance and transpiration rate using the Ll-6400 photosynthesis measuring system (Li-Cor, Inc., Lincoln, NE, USA) at 08:00-11:30 h. The measuring conditions were as follows: $1500 \mu \mathrm{mol} \mathrm{m} \mathrm{m}^{-2} \mathrm{~s}^{-1}$ photosynthetic photon flux density, $25^{\circ} \mathrm{C}$ leaf temperature, $70 \%$ air humidity and $400 \mu \mathrm{mol} \mathrm{mol}^{-1}$ ambient $\mathrm{CO}_{2}$ concentration. In addition, the leaves were extracted in $80 \%$ cooled acetone $(\mathrm{v} / \mathrm{v})$ in the dark until the leaves changed their color to white. Chlorophyll and carotenoid concentrations were 
measured from measurements of solution absorbances at 470, 646 and $663 \mathrm{~nm}$, and calculated according to Chen et al. (2011).

\section{Determination of reactive oxygen species and enzyme activities}

The reactive oxygen species, malondialdehyde (MDA) and enzyme activities were measured according to the method by Chen et al. (2011). For $\mathrm{H}_{2} \mathrm{O}_{2}$, c. $0.2 \mathrm{~g}$ of leaves and roots were ground with liquid nitrogen and then with 5\% trichloroacetic acid, followed by Chen et al. (2011). Briefly, $0.2 \mathrm{ml}$ of clear supernatant was mixed with 1

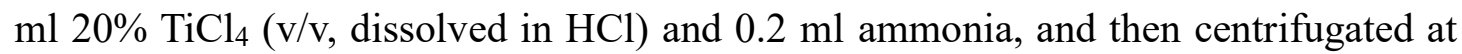
$5000 \mathrm{~g}$ for $10 \mathrm{~min}$. The precipitation was dissolved in $1.5 \mathrm{M} \mathrm{H}_{2} \mathrm{SO}_{4}$, and measured at $410 \mathrm{~nm}$. For $\mathrm{O}_{2}{ }^{-}$determination, the leaves and roots were finely ground with the extraction mixture $\left(50 \mathrm{mM} \mathrm{Na} 2 \mathrm{HPO}_{4}-\mathrm{NaH}_{2} \mathrm{PO}_{4}, \mathrm{pH} 7.8\right)$ and then centrifugated at $12000 \mathrm{~g}$ for $10 \mathrm{~min}$. A volume of $0.5 \mathrm{ml}$ of supernatant was mixed with $0.1 \mathrm{ml}$ hydroxylamine hydrochloride $(10 \mathrm{mM})$. The reaction was conducted at $25^{\circ} \mathrm{C}$ for 30 min. $\mathrm{O}_{2}{ }^{-}$levels were measured colorimetrically at $540 \mathrm{~nm}$ after adding $1 \mathrm{ml}$ of $0.2 \% \mathrm{~N}-$ (1-naphthyl)-ethylene diamine and $1 \mathrm{ml}$ of $1 \%$ sulfanilamide. For MDA, the leaves and roots were ground with $10 \%$ trichloroacetic acid and centrifuged at $12000 \mathrm{~g}$ for $10 \mathrm{~min}$. Then, $0.5 \mathrm{ml}$ of clear supernatant was let to react with $2 \mathrm{ml}$ thiobarbituric acid (0.6\%) in a boiling water bath for $15 \mathrm{~min}$. MDA was measured colorimetrically at 450, 320 and $600 \mathrm{~nm}$, and calculated as follows: $\mathrm{C}(\mathrm{nM})=6.45\left(\mathrm{OD}_{532}-\mathrm{OD}_{600}\right)-0.56 \times \mathrm{OD}_{450}$.

The activities of peroxidase (POD), superoxide dismutase (SOD), glutathione (GR) and 
155

156

157

catalase (CAT) were measured as described by Chen et al. (2011). Proteins were measured using the Bradford method.

\section{Determination of $C d$ and nutrient elements}

Dried leaves and roots were finely ground and dissolved in $3: 1(\mathrm{v} / \mathrm{v})$ of $\mathrm{HNO}_{3}$ and $\mathrm{HClO}_{4}$. Total $\mathrm{Cd}$ and nutrient elements were measured with ICP-MS (inductively coupled plasma mass spectrometer Agilent 7500a, Agilent Technologies). The translocation factor $\left(\mathrm{T}_{\mathrm{f}}\right)$ was defined as the ability for root-to-shoot Cd translocation and calculated as the ratio of Cd concentration in shoots to roots (Shi et al. 2010).

\section{Microscopic imaging of $C d, P$ and $S$ localization in roots, leaf blades and veins}

Leaves and roots were washed carefully with deionized $\mathrm{H}_{2} \mathrm{O}$. Subsequently, the samples were cut into sections and dried with a vacuum freeze dryer for $100 \mathrm{~h}$. The sample surfaces were gold-plated with vacuum sputtering. Photographs were taken under a scanning electron microscope (Zeiss Sigma 500, German) at $3 \mathrm{kV}$. The line scan on the sample surface was conducted with an energy-dispersive x-ray (EDX) (EDAX ELEMENT, America) at $10 \mathrm{kV}$ voltage. The spectra of $\mathrm{Cd}, \mathrm{P}$ and $\mathrm{S}$ on the surface was analyzed with the SuperQuant program (EDAX).

\footnotetext{
Quantitative PCR analyses of gene expression related to Cd uptake and transport
} 
178 Approximately $0.1 \mathrm{~g}$ of roots and leaves was finely ground with liquid nitrogen. Total 179 RNA was isolated using a RNA extraction kit (TaKaRa MiniBEST Plant RNA 180 Extraction Kit, TaKaRa, Otsu, Japan). The first cDNA strand was synthesized using

181

182

183

184

185

186

187

188

189

190

191

192

193

194

195

196

197 The leaves and roots were washed carefully with deionized $\mathrm{H}_{2} \mathrm{O}$. Subsequently, the

PrimeScript reverse transcription (RT) reagent kits (Takara) according to instructions.

Quantitative RT polymerase chain reactions (qRT-PCR) were conducted with One Step

TB Green ${ }^{\mathrm{TM}}$ PrimeScript $^{\mathrm{TM}}$ RT-PCR kits in a $25 \mu$ reaction system with pairs of specific primers (He et al. 2013) (Table S1).

Heavy metal ATPase 2 and 4 (HMA2 and HMA4) proteins facilitate the root-to-shoot translocation of Cd (Li et al. 2018). Metallothionein-like protein (MTP1) and yellow stripe-like protein (YSL2) are responsive for $\mathrm{Cd}$ transportation into the vacuoles (Ricachenevsky et al. 2013). The zinc transporter 2 and 6.2 (ZIP2 and ZIP6.2) regulate the Cd translocation into the cell cytosol of roots (Ma et al. 2014). These genes were analyzed in this study. The primers were similar as those in He et al. (2015). TUB4.1 was used as housekeeping genes. The relative expression of specific genes was calculated according to Liu et al. (2017).

Analysis of Fourier transform infrared spectroscopy (FTIR) samples were dried with a vacuum freeze dryer for $100 \mathrm{~h}$. The freeze-dried powder of 
199

leaves and roots was pressed against the diamond crystal of an attenuated total reflectance device and the infra-red spectra were determined with FTIR spectrometer Nicolet iS5. The scanning range was $400-4000 \mathrm{~cm}^{-1}$ wavenumber.

As shown in Table S2, the differential spectral peaks are at $1651 \mathrm{~cm}^{-1}$ for C-N vibration from protein, at $1419 \mathrm{~cm}^{-1}$ for vibration of $\mathrm{COO}^{-}$from pectin, at $1317 \mathrm{~cm}^{-1}$ for $\mathrm{C}-\mathrm{O}$ vibration from cellulose, at $1151 \mathrm{~cm}^{-1}$ for vibration of $\mathrm{C}-\mathrm{C}$ and $\mathrm{C}-\mathrm{O}$ stretch from carbohydrates (such as soluble sugar, cellulose and hemicellulose), at $1235 \mathrm{~cm}^{-1}$ for $\mathrm{C}=\mathrm{O}$ vibration from xylans and lignin, at $1071 \mathrm{~cm}^{-1}$ for $\mathrm{C}-\mathrm{O}$ from cellulose and hemicellulose, at $1743 \mathrm{~cm}^{-1}$ for vibration of $\mathrm{C}=\mathrm{O}$ from esterified pectin, and at 1111 $\mathrm{cm}^{-1}$ for $\mathrm{C}-\mathrm{C}$ or $\mathrm{C}-\mathrm{O}$ vibration from pectin.

\section{Statistical analysis}

Differences among means within treatments were separated by Duncan's test using the SPSS software (version 22.0) with three-way analyses when $P<0.05$. Data were checked for the normality before analyses. The principal component analysis (PCA) was computed by the command procomp () in $\mathrm{R}$ (http://www.R-project.org/) according to Luo et al. (2019).

\section{Results}


Sexual differences in leaf gas exchange characteristics, pigments and biomass

Cd stress, $\mathrm{N}$ deficiency and the combined stress reduced $\mathrm{A}$ in both sexes, especially in females (Table 1). The stomatal conductance $\left(g_{\mathrm{s}}\right)$ was not affected by stress in females, but it was significantly reduced in males under the combined treatment (Table 1). All stresses increased the intercellular $\mathrm{CO}_{2}$ concentration $\left(C_{\mathrm{i}}\right)$ in both females and males (Table 1). The chlorophyll concentrations of $\mathrm{a}, \mathrm{b}, \mathrm{a}+\mathrm{b}$, and carotenoids were reduced in females, while no change was found in males under any stress. Additionally, N deficiency did not affect these chlorophylls relative to a normal $\mathrm{N}$ supply in either sex exposed to Cd stress.

In females, the dry mass of leaves, stems and roots, and total plant dry mass decreased under nitrogen deficiency and Cd stress, and more seriously under the combined treatment (Table 2). In males, these values decreased under nitrogen deficiency and combined stress, but Cd stress did not affect leaf dry mass when compared to Cd-free conditions. Under control conditions (high N, no Cd), females showed a higher leaf and root dry mass, and total biomass, but a lower stem dry mass when compared to males. In addition, $\mathrm{N}$ deficiency significantly increased the ratio of root to shoot irrespective of the Cd treatment in both sexes.

\section{Sexual differences in oxidative stress and antioxidants}


$\mathrm{N}$ deficiency, $\mathrm{Cd}$ stress and the combined treatment increased $\mathrm{H}_{2} \mathrm{O}_{2}$ and $\mathrm{O}_{2}{ }^{-}$of leaves, and MDA, $\mathrm{H}_{2} \mathrm{O}_{2}$ and $\mathrm{O}_{2}{ }^{-}$of roots in females compared with control plants. Males showed higher $\mathrm{H}_{2} \mathrm{O}_{2}$ in roots and leaves under all stresses when compared to controls. $\mathrm{O}_{2}^{-}$in male roots and leaves was not affected by $\mathrm{Cd}$ stress, but its concentration increased in male roots under $\mathrm{N}$ deficiency, and in leaves under $\mathrm{N}$ deficiency and the combined stress. Furthermore, females showed higher MDA in roots and $\mathrm{O}_{2}{ }^{-}$in leaves under all stress conditions compared to males. There was no significant difference between sexes in leaf MDA under $\mathrm{N}$ deficiency, in leaf $\mathrm{H}_{2} \mathrm{O}_{2}$ under $\mathrm{Cd}$ stress, or in root $\mathrm{H}_{2} \mathrm{O}_{2}$ under the combined treatment. In contrast, males had higher $\mathrm{H}_{2} \mathrm{O}_{2}$ in leaves under the combined treatment and in roots under $\mathrm{N}$ deficiency alone.

In males, $\mathrm{Cd}$ stress, $\mathrm{N}$ deficiency and the combined treatment significantly increased SOD in roots and leaves, as well as CAT in roots, but it did not affect POD and GR in roots (Fig. 2). In females, POD and GR of roots were reduced under all stresses, while CAT of roots and leaves, as well as POD and GR of leaves increased under Cd stress. The combined stress increased CAT and SOD in leaves and SOD in roots in females. When compared to females, males had higher POD in leaves, CAT and POD in roots, and SOD in roots and leaves under the combined treatment (Fig. 2). However, there was no significant difference between sexes in GR of roots under $\mathrm{N}$ deficiency and $\mathrm{Cd}$ stress, and in POD of roots and leaves under the combined stress. CAT in leaves under $\mathrm{N}$ deficiency and the combined stress, and SOD in roots under the combined stress were higher in females than in males. 
Sexual differences in Cd accumulation

267

Elevated Cd exposure strongly increased Cd accumulation in leaves, roots, stem wood woods were not different between females and males under a normal $\mathrm{N}$ supply and $\mathrm{Cd}$ stress $(+\mathrm{N}+\mathrm{Cd})$. When compared to a normal $\mathrm{N}$ supply, $\mathrm{N}$ deficiency combined with

Cd stress strongly promoted $\mathrm{Cd}$ accumulation in leaves, roots and woods of males, and in barks of males showed no differences between $\mathrm{N}$ deficiency and a normal $\mathrm{N}$ supply under Cd stress (Fig. 3). Additionally, males had higher Cd in leaves, roots, woods and barks than females under the combined stress. The translocation factor $\mathrm{T}_{\mathrm{f}}$ was significantly higher in females than in males under Cd stress, but no significant difference was detected under the combined treatment (Fig. S1). used to explore $\mathrm{Cd}$ distribution in the cross-sections of leaf blades, leaf veins and roots. Females had a stronger $\mathrm{Cd}$ signal in leaf vein cross-sections compared to males under control conditions (Fig. 4). $\mathrm{N}$ deficiency reduced Cd allocation into vein cross-sections 
in both sexes, but more strongly in males. Furthermore, in females, a large amount of Cd distributed into epidermal and cortical tissues, as well as into vascular tissues, especially into phloem under a normal $\mathrm{N}$ supply. In contrast, $\mathrm{N}$ deficiency increased $\mathrm{Cd}$ allocation to the leaf vein phloem, epidermis and cortices, especially to the upper epidermis of leaf veins in females (Fig. 4). In males, more Cd was allocated to the cortices of the abaxial veins of leaves, as well as to vascular tissues, especially in xylems. $\mathrm{N}$ deficiency combined with $\mathrm{Cd}$ stress induced considerable $\mathrm{Cd}$ allocation to the epidermis and cortices of the abaxial veins, as well as to xylems in males.

In leaf blade cross-sections, the Cd signal intensity was higher in females than in males under a normal $\mathrm{N}$ supply (Fig. 5). $\mathrm{N}$ deficiency increased the intensity of $\mathrm{Cd}$ signals throughout the male leaf blades, but reduced them in females. Specifically, more Cd distributed into the mesophyll of females, while males had strong $\mathrm{Cd}$ signals in the upper epidermis and mesophyll under a normal $\mathrm{N}$ supply. $\mathrm{N}$ deficiency increased the Cd distribution in epidermal tissues in females, especially in the upper epidermis (Fig. 5). In contrast, more $\mathrm{Cd}$ was allocated to the mesophylls and lower epidermal tissues of male leaf blades under the combined treatment. Furthermore, Cd signals largely distributed in female mesophylls, especially in the palisade tissues, while males had high $\mathrm{Cd}$ in the spongy tissues under a normal $\mathrm{N}$ supply (Fig. 5). $\mathrm{N}$ deficiency largely increased the proportion of Cd allocation to the spongy tissues of leaf blades in both sexes when compared to normal $\mathrm{N}$ supply conditions. 
In roots, males had slightly higher $\mathrm{Cd}$ signals throughout the cross-sections when compared to females under a normal $\mathrm{N}$ supply (Fig. 6). $\mathrm{N}$ deficiency increased $\mathrm{Cd}$ accumulation in the cross-sections of males, but reduced Cd signals in females. Under a normal $\mathrm{N}$ supply, $\mathrm{Cd}$ signals were strongest in the epidermal, cortical and vascular tissues of females, while males had more $\mathrm{Cd}$ in epidermal and cortical tissues. $\mathrm{N}$ deficiency induced more $\mathrm{Cd}$ allocation to epidermal and cortical tissues, and less to vascular tissue in females (Fig. 6). However, more Cd signals were detected in the epidermal, cortical and vascular tissues of males under the combined treatment.

Sexual differences in $S$ and $P$ allocation among tissues

The allocation of $\mathrm{P}$ and $\mathrm{S}$ were also studied in the cross-sections of roots, leaf veins and blades by the application of EDX analysis and SEX imaging. In leaf blades, females had a higher $\mathrm{P}$ to $\mathrm{S}$ ratio, while the contrary was true for males under a normal $\mathrm{N}$ supply (Fig. S2). N deficiency increased the proportion of S in both sexes. Cd stress increased $\mathrm{S}$ in leaf blade cross-sections relative to $\mathrm{P}$ in both sexes, especially in females treated without a $\mathrm{N}$ supply and in males treated with a normal N supply (Fig. 7).

In leaf vein cross-sections, the ratio of $\mathrm{S}$ to $\mathrm{P}$ signal was higher in epidermal and cortical tissues of females when compared to males but not in vascular tissues (Fig. S2). Males had stronger $\mathrm{S}$ signals than $\mathrm{P}$ signals under a normal $\mathrm{N}$ supply, and $\mathrm{S}$ and $\mathrm{P}$ were uniformly distributed throughout the cross-sections of leaf veins under both $\mathrm{N}$ levels 
( $\mathrm{N}$ deficiency, normal $\mathrm{N}$ supply). In females, $\mathrm{N}$ deficiency induced $\mathrm{P}$ allocation to vascular tissues, but the proportions of $\mathrm{P}$ and $\mathrm{S}$ were similar in epidermal and cortical tissues. Cd stress significantly increased S throughout leaf vein cross-sections in both sexes, especially in males (Fig. 7). Moreover, $\mathrm{P}$ and $\mathrm{S}$ were mainly distributed in the vascular tissues of males under $\mathrm{N}$ deficiency. The proportion of $\mathrm{S}$ relative to $\mathrm{P}$ in roots was highest in $\mathrm{N}$-sufficient females and $\mathrm{N}$-deficient males (Fig. S2). Cd stress increased $\mathrm{P}$ in female roots under a normal $\mathrm{N}$ supply and $\mathrm{P}$ of males under $\mathrm{N}$ deficiency relative to Cd-free controls (Fig. 7).

FTIR spectra of roots and leaves

To investigate the effect of $\mathrm{Cd}$ on the chemical fingerprint of the molecular composition of the cell wall, we measured the absorption spectra peaks of leaves and roots. In this study, PCA analysis was performed to study the original absorbance data. In leaves, PC1 and PC2 accounted for $92 \%$ and $2 \%$ of the variation, respectively (Fig. 8; Table S3). Peaks at $1651,1419,1317 \mathrm{~cm}^{-1}$ were the most vital contributors to PC1, whereas peaks 1111 and $1541 \mathrm{~cm}^{-1}$ were the key factors contributing to PC2. In roots, PC1 and PC2 accounted for $95 \%$ and $2 \%$ of the variation, respectively. In the PCA plot of roots, peaks $1419,1317,1111$ and $1157 \mathrm{~cm}^{-1}$ were key factors contributing to $\mathrm{PC} 1$, whereas peaks at $3360 \mathrm{~cm}^{-1}$ and $2915 \mathrm{~cm}^{-1}$ were main contributors to PC2 (Fig. 8; Table S4). The PCA results indicated that males showed more significant changes in the chemical composition of leaves and roots compared with females under both $\mathrm{N}$ supply levels, but 
353

354

355

357

especially under a normal $\mathrm{N}$ supply, reflecting the absorption by the groups related to lignin, cellulose, hemicellulose and pectin in roots and leaves.

PCA of physiological responses

To uncover the main factors participating in the adaptive responses of females and males to $\mathrm{Cd}$ stress and $\mathrm{N}$ deficiency, PCA was performed using traits related to photosynthesis, growth, element concentrations, oxidative stress and antioxidative capacity (Fig. 9; Table S5). PC1 and PC2 accounted for 40\% and 19\% of the variation, respectively. Shoot dry mass, stem mass, net photosynthesis rate and leaf $\mathrm{H}_{2} \mathrm{O}_{2}$ levels were key factors contributing to $\mathrm{PC} 1$, while root $\mathrm{H}_{2} \mathrm{O}_{2}$ levels, $g_{s}$ and transpiration rates were the three most important factors contributing to PC2. The PCA separated females from males in responses to $\mathrm{Cd}$ stress and $\mathrm{N}$ deficiency.

\section{Transcript levels of genes involved in Cd translocation and uptake}

We analyzed the genes related to $\mathrm{Cd}$ translocation and tolerance in roots. $\mathrm{Cd}$ induced the expression of HMA2 and HMA4 genes in female roots, whereas in male roots $\mathrm{Cd}$ stress downregulated HMA2i but did not affect HMA4 expression compared to the controls (Fig. 10). $\mathrm{N}$ deficiency did not affect the expressions of HMA2 and HMA4 in female roots, but it upregulared the expression of HMA2 under $\mathrm{Cd}$ stress compared to controls. Cd stress induced MTP1 gene expression in female roots, especially under $\mathrm{N}$ 
deficiency, while the transcription of MTP1 in male roots was strongly induced by $\mathrm{Cd}$ stress but down-regulated under the combined stress. The expression of YSL2 in roots was induced in females by Cd stress but inhibited in males, while it was upregulated by the combined stress in both sexes. The transcription levels of ZIP2 and ZIP6.2 genes in male roots and ZIP2 of female roots were upregulated by Cd stress irrespective of the $\mathrm{N}$ status, while the expression of ZIP6.2gene in female roots was not affected by $\mathrm{Cd}$ stress but downregulated under the combined stress.

\section{Discussion}

Sexually different physiological tolerance to $C d$ stress and $N$ deficiency

Cadmium interferes with plant growth and metabolism, but the toxic effects of $\mathrm{Cd}$ differ among plant species (Baliardini et al. 2015, He et al. 2015). In this study, Cd stress significantly reduced A and leaf dry mass in females but not in males under a normal $\mathrm{N}$ supply (Tables 1, 2). This result is consistent with previous studies (Chen et al. 2011; Chen et al. 2016). Noticeably, the damage on photosynthesis and biomass accumulation was smaller in males than in females under the combined stress (Table 2). Interestingly, we also found that males showed no significant symptoms of $\mathrm{Cd}$ toxicity irrespective of the $\mathrm{N}$ supply, while clear $\mathrm{Cd}$ toxicity symptoms were found in the abaxial leaves of females under a normal $\mathrm{N}$ supply but not under $\mathrm{N}$ deficiency (Fig. S3). It could be inferred that males have a far stronger Cd tolerance compared to females, especially 
under a normal $\mathrm{N}$ supply (Fig. S3). Yet, Cd toxicity symptoms of females did not differ much between $\mathrm{N}$ deficiency and a normal $\mathrm{N}$ supply, which could be explained by the reduced Cd translocation to leaves (Fig. S1). Our results appeared different from those of Chen et al (2011), who proposed that $\mathrm{N}$ deposition decreases differences in $\mathrm{Cd}$ sensitivity in Populus yunnanensis females and males. However, the $\mathrm{N}$ supply level and species were different in the study by Chen et al (2011). They used normal and higher $\mathrm{N}$ applications, while we used $\mathrm{N}$ deficiency and a normal $\mathrm{N}$ supply. It seems that the $\mathrm{N}$ availability ( $\mathrm{N}$ deficiency, normal $\mathrm{N}$ and high $\mathrm{N}$ ) differently affects the responses of females and males to Cd stress.

Cd accumulation in leaves disrupts photosynthesis (Fei et al. 2018). Thus, the inhibition of $\mathrm{Cd}$ translocation to the shoots is probably an effective approach to enhance $\mathrm{Cd}$ tolerance (Daud et al. 2015, Fei et al. 2018). Cd uptake, root-to-shoot translocation and accumulation in leaves were largely induced under a normal $\mathrm{N}$ supply, while $\mathrm{N}$ deficiency reduced $\mathrm{Cd}$ accumulation in the leaves of females (Fig. 3). This is in accordance with previous studies (Chang et al., 2013, Hu et al., 2013). The lower Cd accumulation in female leaves under $\mathrm{N}$ deficiency is probably a self-protecting strategy to cope with Cd toxicity, as described by Zhang et al (2019), who suggested that lower $\mathrm{Cd}$ accumulation in Populus leaves might be a self-protecting strategy to prevent severe oxidative damage due to a decreased stress tolerance under $\mathrm{N}$ deficiency. Cheng et al (2017) also suggested that ammonium-based fertilizers enhance $\mathrm{Cd}$ accumulation in Carpobrotus rossii. However, this is not the case in P. cathayana males, since more $\mathrm{Cd}$ 
accumulated in leaves under $\mathrm{N}$ deficiency than under a normal $\mathrm{N}$ supply (Fig. 3). Similarly, Konotop et al (2012) suggested that a nitrogen application decreases Cd uptake and improves Cd tolerance in soybean seedlings. Perilli et al (2010) have also proposed that cadmium concentrations of wheat are influenced by the nitrogen level, seedling age and soil type. The greater $\mathrm{Cd}$ accumulation in male leaves under $\mathrm{N}$ deficiency is probably correlated with $\mathrm{N}$ sensitivity, since males have a lower resource consumption and stronger tolerance to $\mathrm{N}$ deficiency compared to females. Moreover, the capacity for antioxidation defense was significantly elevated by $\mathrm{N}$ deficiency in males (Fig. 2). Evidently, males and females employ different mechanisms to cope with Cd toxicity, especially under $\mathrm{N}$ deficiency.

Changed nutrient allocation and oxidative-antioxidation homeostasis in females and males under $N$ deficiency highlight the physiological regulation mechanism of $C d$

Populus species are characterized by dioecy, which is usually associated with sexual dimorphism. Females generally allocate more resources to reproduction and males often increase investment in defense (Juvany \& Munné-Bosch, 2015). Sulfur compounds, such as GSH, PCs and metallothionein, act as antioxidants or chelators involved in plant tolerance to heavy metals (Cobbett \& Goldsbrough 2002, Li et al. 2019). Therefore, $P$ and $S$ allocation to roots, leaf blades and veins exposed to $C d$ stress were analyzed in this study (Fig. 7). Females had higher proportions of P relative to $S$ in leaves under control conditions, especially in leaf blades, which is consistent with 
441

their higher reproductive investment (Graff et al. 2013). In contrast, the proportion of $\mathrm{S}$ relative to $\mathrm{P}$ was higher in males under control conditions, which is consistent with their stronger tolerance to stress (He et al. 2013). S and P allocations were closely correlated with Cd throughout cross-sections of leaf blades and veins in both sexes, especially in males under a normal $\mathrm{N}$ supply and in females under $\mathrm{N}$ deficiency (Figs. 4-7). Cd detoxification by S has been previously reported (Sarwar et al. 2010, Chen et al. 2015). In addition, He et al (2015) found in poplars that S was significantly correlated with $\mathrm{Cd}$ and it increased GSH synthesis through the overexpression of bacterial $\gamma$-glutamylcysteine synthetase facilitated by $\mathrm{Cd}$ detoxification and enhanced Cd tolerance. Hence, the stronger tolerance of males is probably attributable to the high proportion of $\mathrm{S}$ in males under $\mathrm{Cd}$ stress. It should be noted that $\mathrm{N}$ deficiency increased the proportion of $\mathrm{P}$ in males under $\mathrm{Cd}$ stress. $\mathrm{P}$ is involved in $\mathrm{PC}$ biosynthesis, $\mathrm{Cd}$ is transported into vacuoles by $\mathrm{Cd} / \mathrm{PC}$ complexes, and $\mathrm{Cd}$ is sequestrated into cell walls through an association with phosphates (Parrotta et al. 2015). Hence, the increase in $\mathrm{P}$ induced by $\mathrm{N}$ deficiency probably plays an important role in the Cd tolerance of males.

Cd toxicity is often accompanied with a ROS burst, which causes the disruption of redox homeostasis, followed by oxidative damage on plant cells (Rui et al. 2016, Gupta et al. 2017). The present study found that $\mathrm{Cd}$ induces oxidative damage more seriously in females than in males, especially by $\mathrm{O}_{2}^{-}$in leaves and by MDA in roots (Fig. 1). ROS act to stimulate an early defective response (Liu et al. 2018a, b), and elevated $\mathrm{H}_{2} \mathrm{O}_{2}$ levels detected in male and female leaves and roots are early signals of adaptive 
responses to stress, including the induction of antioxidants. Antioxidants, such as GR, SOD, POD and CAT, are regarded as main enzymatic antioxidants scavenging the detrimental effects of ROS in plants (Schutzendubel et al. 2001). Cd stress reduced CAT, POD and GR activities in female leaves and roots but had little effect on males compared to controls (Fig. 2). Furthermore, although $\mathrm{N}$ deficiency promoted $\mathrm{Cd}$ accumulation in male leaves but reduced that in females, females were still more sensitive to Cd stress compared to males.

Sexually different $C d$ sequestration and accumulation among tissues under $N$ deficiency highlight the mechanism of Cd tolerance

It is worth noting that $\mathrm{N}$ deficiency reduced Cd uptake and/or translocation in females but increased those in males under Cd stress. The extensive $\mathrm{Cd}$ accumulation in shoots without toxicity symptoms is similar as what happens in hyperaccumulator plants, which are characterized by a high capacity of root-to-shoot translocation (Lu et al. 2013). We found that genes related to Cd uptake and translocation, such as HMA2 and HMA4, YSL2 and ZIP2, were strongly induced by Cd stress in female roots under a normal $\mathrm{N}$ supply (Fig. 10). In male roots, the expression of HMA2, YSL2 and ZIP6 genes were significantly induced by $\mathrm{N}$ deficiency. Additionally, strong sequestration into the cell walls of male roots under a normal $\mathrm{N}$ supply reduced $\mathrm{Cd}$ accumulation in shoots (Fig. 8). 
485

486

487

488

489

490

491

492

493

494

495

496

497

498

499

500

501

502

503

504

505

506

Males showed a better Cd tolerance when compared to females under both $\mathrm{N}$ supply levels, although $\mathrm{N}$ deficiency promoted Cd uptake and/or translocation from roots to shoots in males (Fig. 3, Fig. S1). This is consistent with observations on the hyperaccumuating ecotype of Sedum alfredii Hance, in which Cd accumulates in shoots without toxicity symptoms (Tian et al. 2017). Successful Cd detoxification probably requires effective sequestration of $\mathrm{Cd}$ into organs ( $\mathrm{Lu}$ et al. 2013), and effective $\mathrm{Cd}$ sequestration among tissues and cellular compartments, as observed in P. cathayana males, is probably accomplished as a permanent Cd storage (Tian et al. 2009). We found that Cd largely accumulates in male bark, especially under $\mathrm{N}$ deficiency (Fig. 3), which is consistent with previous investigations (He et al. 2013). Epidermal Cd increased in leaf veins and blades, primarily in the upper leaf epidermis and spongy tissues of males, especially under $\mathrm{N}$ deficiency, perhaps protecting leaf mesophylls and guard cells against Cd toxicity (Figs. 4-5). Furthermore, successful Cd detoxification probably need effective sequestration in appropriate cellular compartments to accomplish the status of permanent storage (Tian et al. 2013). The cell walls and vacuoles are suggested to effectively sequestrate $\mathrm{Cd}$ and reduce cytosolic Cd levels in plants (Peng et al. 2017, Zhang et al. 2018). In this study, Cd stress induced the expression of HMA2, HMA4 and MTP1 genes in male leaves, especially the expression of MTP 1 under N deficiency (Fig. S4). Additionally, the higher ratio between males and females at 1419, 1317, 1111 and $1157 \mathrm{~cm}^{-1}$ of FTIR suggested that higher pectin and lignin levels probably contributed to Cd detoxification in males. 


\section{Conclusions}

The present study suggests that one of the primary factors responsible for a greater $\mathrm{Cd}$ allocation to leaves and sensitivity in females is ineffective $\mathrm{Cd}$ sequestration in organs and/or cellular compartments (Fig. 11). Moreover, the more extensive root-to-shoot translocation of $\mathrm{Cd}$ and the weaker $\mathrm{Cd}$ detoxification in females also led to their greater sensitivity to Cd toxicity, irrespectively of the $\mathrm{N}$ supply. Although $\mathrm{N}$ deficiency reduced the Cd root-to-shoot translocation in females and elevated that in males, males had a better Cd tolerance compared to females under Cd stress. It follows that it may be important to modify artificially the soil $\mathrm{N}$ status depending on the Cd tolerance of $P$. cathayana females and males. In all, our investigation provides new insights into efforts aiming to engineer woody plants for phytoremediation.

Acknowledgements This work was supported by the Natural Science Foundation of China (31800507) and the Talent Program of the Hangzhou Normal University (2016QDL020).

Author contributions Miao Liu had the main responsibility for data collection, analysis and writing, Jingwen $\mathrm{Bi}$, Xiucheng Liu and Jieyu Kang contributed to data collection and analysis, Helena Korpelainen and Ülo Niinemets contributed to the interpretation of data and manuscript preparation, and Chunyang $\mathrm{Li}$ (the corresponding author) had the overall responsibility for experimental design and project management. 
530 Conflict of interest The authors declare that they have no conflict of interest.

532 Supporting Information Additional supporting information and references can be 533 found in the supplementary information.

\section{References}

Baliardini C, Meyer CL, Salis P, Saumitou-Laprade P, Verbruggen N (2015) CAX1 cosegregates with Cd tolerance in the metal hyperaccumulator Arabidopsis halleri and plays a role in limiting oxidative stress in Arabidopsis. Plant Physiol 169: 549-559. 324.

Chang YS, Chang YJ, Lin CT, Lee MC, Wu CW, Lai YH (2013) Nitrogen fertilization promotes the phytoremediation of cadmium in Pentas lanceolata. Int Biodeter Biodegr 85: 709-714.

546 Chen J, Duan B, Xu G, Korpelainen H, Niinemets Ü, Li C (2016) Sexual competition 547 affects biomass partitioning, carbon-nutrient balance, $\mathrm{Cd}$ allocation and $548 \quad$ ultrastructure of Populus cathayana females and males exposed to Cd stress. Tree 549 Physiol 36: 1353-1368.

550 Chen J, Han Q, Duan B, Korpelainen H, Li C (2017) Sex-specific competition 
551 differently regulates ecophysiological responses and phytoremediation of Populus 552 cathayana under Pb stress. Plant Soil 421: 203-218.

553 Chen L, Han Y, Jiang H, Korpelainen H, Li C (2011) Nitrogen nutrient status induces 554 sexual differences in responses to cadmium in Populus yunnanensis. J Exp Bot 62: $555 \quad 5037-5050$.

556 Chen J, Yang LB, Gu J, Bai XY, Ren YB, Fan TT, Han Y, Jiang L, Xiao FM, Liu YS, 557 Cao SQ (2015) MAN3 gene regulates cadmium tolerance through the glutathione558 dependent pathway in Arabidopsis thaliana. New Phytol 205: 570-582.

559 Cheng MM, Wang A, Tang CX 2017 Ammonium-based fertilizers enhance Cd 560 accumulation in Carpobrotus rossii grown in two soils differing in $\mathrm{pH}$. Chemosphere 561 188: 689-696.

562 Cobbett C \& Goldsbrough P (2002) Phytochelatins and metallothioneins: roles in heavy 563 metal detoxification and homeostasis. Ann Rev Plant Biol 53: 159-182.

564 Daud MK, Quiling H, Lei M, Ali B, Zhu SJ (2015) Ultrastructural, metabolic and 565 proteomic changes in leaves of upland cotton in response to cadmium stress. 566 Chemosphere 120: 309-320.

567 Erenoglu EB, Kutman UB, Ceylan Y, Yildiz B, Cakmak I (2011) Improved nitrogen 568 nutrition enhances root uptake, root-to-shoot translocation and remobilization of zinc $569 \quad\left(65^{\mathrm{Zn}}\right)$ in wheat. New Phytol 189(2): 438-448.

570 Erdal S, Turk H (2016) Cysteine-induced upregulation of nitrogen metabolism-related 571 genes and enzyme activities enhance tolerance of maize seedlings to cadmium stress.

572 Environ Exp Bot 132: 92-99. 
573 Fei L, Xu P, Dong Q, Mo Q, Wang Z (2018) Young leaf protection from cadmium 574 accumulation and regulation of nitrilotriacetic acid in tall fescue (Festuca 575 arundinacea) and Kentucky bluegrass (Poa pratensis). Chemosphere 212: 124-132.

576 Graff P, Rositano F, Aguiar MR (2013) Changes in sex ratios of a dioecious grass with 577 grazing intensity: the interplay between gender traits, neighbor interactions and $578 \quad$ spatial patterns. J Ecol 101: 1146-1157.

579 Godt J, Scheidig F, Grosse-Siestrup C, Esche V, Brandenburg P, Reich A, Groneberg 580 DA 2006 The toxicity of cadmium and resulting hazards for human health. Journal 581 of occupational medicine and toxicology 1(1): 22.

582 Gupta DK, Pena LB, Romero-Puertas MC, Hernández A, Inouhe M, Sandalio LM 583 (2017) NADPH oxidases differentially regulate ROS metabolism and nutrient uptake $584 \quad$ under cadmium toxicity. Plant Cell Environ 40: 509-526.

585 He JL, Li H, Luo J, Ma CF, Li SJ, Qu L, Gai Y, Jiang XN, Janz D, Polle A, Tyree M 586 (2013) A transcriptomic network underlies microstructural and physiological 587 responses to cadmium in Populus $\times$ canescens. Plant Physiol162: 424-439.

588 He JL, Li H, Ma CF, Zhang YL, Polle A, Rennenberg H, Cheng XQ, Luo ZB (2015) 589 Overexpression of bacterial $\gamma$-glutamylcysteine synthetase mediates changes in 590 cadmium influx, allocation and detoxification in poplar. New Phytol 205: 240-254. 591 Hu P, Yin YG, Ishikawa S, Suzui N, Kawachi N, Fujimaki S, Igura M, Yuan C, Li HZ, 592 et al (2013) Nitrate facilitates cadmium uptake, transport and accumulation in the 593 hyperaccumulator Sedum plumbizincicola. Environ Sci Pollut R 20(9): 6306-6316. 
595 M, Massacci A, Sabatti M (2016) Physiology and genetic architecture of traits 596 associated with cadmium tolerance and accumulation in Populus nigra L. Trees 30: $597 \quad 125-139$.

598 Juvany M, Munné-Bosch S (2015) Sex-related differences in stress tolerance in 599 dioecious plants: a critical appraisal in a physiological context. J Exp Bot 66: 6083$600 \quad 6092$.

601 Konotop Y, Mezsaros P, Matusikova I, Batsmanova L, Taran N (2012) Application of 602 nitrogen nutrition for improving tolerance of soybean seedlings to cadmium. Environ $603 \quad$ Exp Biol 10: 139-144.

604 Li NN, Xiao H, Sun JJ, Wang SF, Wang, JC, Chang P, Zhou XB, Lei B, Lu Kun, Luo F 605 et al (2018) Genome-wide analysis and expression profiling of the $H M A$ gene family 606 in Brassica napus under cd stress. Plant Soil 426: 365-381.

607 Li Y, Duan B, Chen J, Korpelainen H, Niinemets Ü, Li C (2016) Males exhibit 608 competitive advantages over females of Populus deltoides under salinity stress. Tree $609 \quad$ Physiol 36: 1573-1584.

610 Li Y, Liu K, Wang Y, Zhou Z, Chen C, Ye P, Yu F (2018) Improvement of cadmium 611 phytoremediation by Centella asiatica L. after soil inoculation with cadmium612 resistant Enterobacter sp. FM-1. Chemosphere 202: 280-288.

613 Li XZ, Yu H, Sun XW, Yang JT, Wang D,C Shen LF, Pan YS, Wu YC, Wang Q, Zhao 614 Y (2019) Effects of sulfur application on cadmium bioaccumulation in tobacco and 615 its possible mechanisms of rhizospheric microorganisms. J Hazard Mater 368: 308315. 
617

618

619

620

621

622

623

624

625

626

627

628

629

630

631

632

633

634

635

636

637

638

Liu M, Liu XX, He XL, Liu LJ, Wu H, Tang CX, Zhang YS, Jin CW (2017) Ethylene and nitric oxide interact to regulate the magnesium deficiency-induced root hair development in Arabidopsis. New Phytol 213: 1242-1256.

Liu M, Bi JW, Jin CW (2018a) Developmental responses of root hairs to Mg deficiency. Plant Signaling \& Behavior 13: e1500068.

Liu M, Zhang HH, Fang XZ, Zhang Y, Jin CW (2018b) Auxin acts downstream of ethylene and nitric oxide to regulate magnesium deficiency-induced root hair development in Arabidopsis thaliana. Plant Cell Physiol 59: 1452-1465.

Liu M, Sun J, Li Y, Xiao Y (2017) Nitrogen fertilizer enhances growth and nutrient uptake of Medicago sativa inoculated with Glomus tortuosum grown in Cdcontaminated acidic soil. Chemosphere 167: 204-211.

Liao Q, Jian SF, Song HX, Guan CY, Lepo JE, Ismail AM, Zhang ZH (2019) Balance between nitrogen use efficiency and cadmium tolerance in Brassica napus and Arabidopsis thaliana. Plant Sci (online).

Lu L, Tian S, Zhang J, Yang X, Labavitch JM, Webb SM, Latimer M, Brown PH (2013) Efficient xylem transport and phloem remobilization of $\mathrm{Zn}$ in the hyperaccumulator plant species Sedum alfredii. New Phytol 198: 721-731.

Luo J, Zhou JJ, Masclaux-Daubresse C, Wang N, Wang H, Zheng B (2019) Morphological and physiological responses to contrasting nitrogen regimes in Populus cathayana is linked to resources allocation and carbon/nitrogen partition. Environ Exp Bot 162: 247-255.

Ma YL, He JL, Ma, CF, Luo J, Li H, Liu TX, Polle A, Peng CH, LUO ZB (2014) 
639 Ectomycorrhizas with Paxillus involutus enhance cadmium uptake and tolerance in 640 Populus $\times$ canescens. Plant, Cell Environ 37: 627-642.

641 Mao QQ, Guan MY, Lu KX, Du ST, Fan SK, Ye YQ, Lin XY, Jin CW (2014) Inhibition 642 of nitrate transporter 1.1-controlled nitrate uptake reduces cadmium uptake in 643 Arabidopsis. Plant Physiol 166: 934-944.

644 Meyer CL, Pauwels M, Briset L, Godé C, Salis P, Bourceaux A, Souleman D, Frérot H, 645 Verbruggen N (2016) Potential preadaptation to anthropogenic pollution: evidence 646 from a common quantitative trait locus for zinc and cadmium tolerance in 647 metallicolous and nonmetallicolous accessions of Arabidopsis halleri. New Phytol $648 \quad 212: 934-943$.

649 Meyer CL, Juraniec M, Huguet S, Chaves-Rodriguez E, Salis P, Isaure MP, 650 Goormaghtigh, Verbruggen N (2015) Intraspecific variability of cadmium tolerance 651 and accumulation, and cadmium-induced cell wall modifications in the metal 652 hyperaccumulator Arabidopsis halleri. J Exp Bot 66: 3215-3227.

653 Parrotta L, Guerriero G, Sergeant K, Cai G, Hausman JF (2015) Target or barrier? The 654 cell wall of early-and later-diverging plants vs cadmium toxicity: differences in the 655 response mechanisms. Front Plant Sci 6: 133.

656 Perilli P., Mitchell LG, Grant CA, Pisante M (2010) Cadmium concentration in durum 657 wheat grain (Triticum turgidum) as influenced by nitrogen rate, seeding date and soil 658 type. J Sci Food Agr 90(5): 813-822.

659 Peng JS, Wang YJ, Ding G, Ma HL, Zhang YJ, Gong JM (2017) A pivotal role of cell 660 wall in cadmium accumulation in the Crassulaceae hyperaccumulator Sedum 
662

663

664

665

666

667

668

669

670

671

672

673

674

675

676

677

678

679

680

681

682

Ricachenevsky FK, Menguer PK, Sperotto RA, Williams LE, Fett JP (2013) Roles of plant metal tolerance proteins (MTP) in metal storage and potential use in biofortification strategies. Front Plant Sci 4: 144.

Rui H, Chen C, Zhang X, Shen Z, Zhang F (2016) Cd-induced oxidative stress and lignification in the roots of two Vicia sativa L. varieties with different $\mathrm{Cd}$ tolerances. J Hazard Mater 301: 304-313.

Sarwar N, Malhi SS, Zia MH., Naeem A, Bibi S, Farid G (2010) Role of mineral nutrition in minimizing cadmium accumulation by plants. J Sci Food Agr 90: 925937.

Schutzendubel A, Schwanz P, Teichmann T, Gross K, Langenfeld-Heyser R, Godbold Rizwan M, Ali S, Ali B, Adrees M, Arshad M et al (2019) Zinc and iron oxide nanoparticles improved the plant growth and reduced the oxidative stress and cadmium concentration in wheat. Chemosphere 214: 269-277.

Sharma A, Sainger M, Dwivedi S, Srivastava S, Tripathi RD, Singh RP (2010) Genotypic variation in Brassica juncea (L.) Czern. cultivars in growth, nitrate assimilation, antioxidant responses and phytoremediation potential during cadmium stress. Journal of Environmental Biology 31: 773.

Sharma SS, Dietz KJ (2006) The significance of amino acids and amino acid-derived molecules in plant responses and adaptation to heavy metal stress. J Exp Bot 57: 711726.

Tian SK, Lu LL, Yang XE, Labavitch JM, Huang YY, Brown P (2009) Stem and leaf 

sequestration of zinc at the cellular level in the hyperaccumulator Sedum alfredii. $684 \quad$ New Phytol 182: 116-126.

685 Tian SK, Xie RH, Wang HX, Hu Y, Hou DD, Liao XC, Brown PH, Yang XE, Liu XY, 686 Labavitch JM et al (2017) Uptake, sequestration and tolerance of cadmium at cellular 687 levels in the hyperaccumulator plant species Sedum alfredii. J Exp Bot 68: 2387$688 \quad 2398$.

689 Yang S, Zu Y, Li B, Bi Y, Jia L, He Y, Li Y (2019) Response and intraspecific differences 690 in nitrogen metabolism of alfalfa (Medicago sativa L.) under cadmium stress. 691 Chemosphere 220: 69-76.

692 Zhang J, Martinoia E, Lee Y (2018) Vacuolar transporters for cadmium and arsenic in 693 plants and their applications in phytoremediation and crop development. Plant Cell $694 \quad$ Physiol 59: 1317-1325.

695 Zhang S, Yang C, Chen M, Chen J, Pan Y, Chen Y, Pan YH, Chen YG, Rahman SU, 696 Fan JF, Zhang, Y (2019) Influence of nitrogen availability on Cd accumulation and 697 acclimation strategy of Populus leaves under Cd exposure. Ecotox Environ Safe 180: $698 \quad 439-448$.

699 Zhao H, Li Y, Duan B, Korpelainen H, Li C (2009) Sex-related adaptive responses of 700 Populus cathayana to photoperiod transitions. Plant Cell Environ 32(10): 1401-1411. 
1 Table 1. Net photosynthesis rate $(A)$, stomatal conductance $\left(g_{\mathrm{s}}\right)$, transpiration $(E)$, chlorophyll a $(\mathrm{Chl} \mathrm{a}), \mathrm{Chl} \mathrm{b}$ and $\mathrm{Chl}(\mathrm{a}+\mathrm{b})$, and carotenoid $(\mathrm{Car})$

2 in leaves of Populus cathayana females and males, as affected by cadmium stress, $\mathrm{N}$ deficiency and their combination.

\begin{tabular}{|c|c|c|c|c|c|c|c|c|}
\hline Sex & Treatment & $\bar{A}$ & $g_{\mathrm{s}}$ & $E$ & Chl a & Chl b & Chl $(a+b)$ & Car \\
\hline \multirow[t]{4}{*}{$\overline{\text { Female }}$} & $+\mathrm{N}-\mathrm{Cd}$ (Control) & $17.37 \pm 0.80 \mathrm{c}$ & $0.223 \pm 0.026 \mathrm{c}$ & $4.00 \pm 0.48 \mathrm{~d}$ & $1.79 \pm 0.031 \mathrm{a}$ & $0.410 \pm 0.031 \mathrm{a}$ & $2.20 \pm 0.074 \mathrm{a}$ & $0.897 \pm 0.029 a$ \\
\hline & $-\mathrm{N}-\mathrm{Cd}$ & $10.11 \pm 1.07 \mathrm{ef}$ & $0.223 \pm 0.035 \mathrm{c}$ & $3.80 \pm 0.44 \mathrm{~d}$ & $0.851 \pm 0.13 c$ & $0.260 \pm 0.091 \mathrm{c}$ & $1.11 \pm 0.23 \mathrm{c}$ & $0.587 \pm 0.017 \mathrm{~cd}$ \\
\hline & $+\mathbf{N}+\mathbf{C d}$ & $12.69 \pm 1.66 \mathrm{~d}$ & $0.194 \pm 0.024 c$ & $3.52 \pm 0.31 \mathrm{~d}$ & $1.42 \pm 0.13 b$ & $0.394 \pm 0.14 \mathrm{ab}$ & $1.82 \pm 0.26 \mathrm{~b}$ & $0.492 \pm 0.093 \mathrm{~d}$ \\
\hline & $-\mathrm{N}+\mathrm{Cd}$ & $9.56 \pm 0.64 f$ & $0.203 \pm 0.029 c$ & $3.98 \pm 0.37 \mathrm{~d}$ & $0.910 \pm 0.097 \mathrm{c}$ & $0.248 \pm 0.035 \mathrm{c}$ & $1.16 \pm 0.18 \mathrm{c}$ & $0.509 \pm 0.012 \mathrm{~d}$ \\
\hline \multirow[t]{4}{*}{ Male } & $+\mathrm{N}-\mathrm{Cd}$ (Control) & $20.96 \pm 1.40 \mathrm{a}$ & $0.368 \pm 0.083 \mathrm{ab}$ & $5.31 \pm 0.87 \mathrm{ab}$ & $1.73 \pm 0.076 \mathrm{a}$ & $0.419 \pm 0.11 \mathrm{a}$ & $2.15 \pm 0.12 \mathrm{a}$ & $0.769 \pm 0.01 \mathrm{ab}$ \\
\hline & $-\mathrm{N}-\mathrm{Cd}$ & $12.26 \pm 0.26 \mathrm{~d}$ & $0.326 \pm 0.052 b$ & $4.97 \pm 0.52 b c$ & $1.34 \pm 0.048 b$ & $0.304 \pm 0.50 \mathrm{bc}$ & $1.65 \pm 0.88 b$ & $0.694 \pm 0.010 b c$ \\
\hline & $+\mathbf{N}+\mathbf{C d}$ & $19.01 \pm 1.40 \mathrm{~b}$ & $0.409 \pm 0.06 \mathrm{a}$ & $6.07 \pm 0.70 \mathrm{a}$ & $1.71 \pm 0.21 \mathrm{a}$ & $0.400 \pm 0.063 \mathrm{ab}$ & $2.11 \pm 0.23 \mathrm{a}$ & $0.741 \pm 0.20 \mathrm{~b}$ \\
\hline & $-\mathrm{N}+\mathrm{Cd}$ & $11.49 \pm 1.53 \mathrm{de}$ & $0.231 \pm 0.068 \mathrm{c}$ & $4.10 \pm 0.89 \mathrm{~cd}$ & $1.40 \pm 0.12 b$ & $0.359 \pm 0.029 \mathrm{ab}$ & $1.76 \pm 0.15 b$ & $0.754 \pm 0.13 b$ \\
\hline $\mathbf{P}_{\mathbf{s}}$ & & $* * *$ & $* * *$ & $* * *$ & ns & ns & ns & $* * *$ \\
\hline $\mathbf{P}_{\text {cd }}$ & & $* * *$ & ns & $*$ & $* *$ & $\mathrm{~ns}$ & $* *$ & $* *$ \\
\hline $\mathbf{P}_{\mathbf{n}}$ & & $* * *$ & $* *$ & $* * *$ & $* * *$ & $* * *$ & $* * *$ & $* * *$ \\
\hline $\mathbf{P}_{\mathbf{s} \times \mathbf{c d}}$ & & ns & ns & ns & ns & ns & ns & $* * *$ \\
\hline $\mathbf{P}_{\mathbf{s} \times \mathbf{n}}$ & & $* * *$ & $* *$ & ns & $*$ & ns & ns & $\mathrm{ns}$ \\
\hline $\mathbf{P}_{\mathbf{c d} \times \mathbf{n}}$ & & $* *$ & ns & $* * *$ & $* *$ & ns & $*$ & $* *$ \\
\hline $\mathbf{P}_{\mathbf{s} \times \mathbf{c d} \times \mathbf{n}}$ & & ns & ns & ns & nsns & ns & ns & ns \\
\hline
\end{tabular}

3

$4 F_{s}$, sex effect; $P_{c d}, \mathrm{Cd}$ effect; $P_{n}, \mathrm{~N}$ effect; $P_{s \times c d}$, the interaction effect of sex and Cd. $P_{s \times n}$, the interaction effect of sex and N; $P_{c d \times n}$, the interaction

5 effect of $\mathrm{Cd}$ and $\mathrm{N} ; F_{s \times c d \times n}$, the interaction effect of sex, $\mathrm{Cd}$ and $\mathrm{N}$. Different letters on the bars indicate significant differences between the

6 treatments $(P<0.05$, Duncan's test). The significance values of the three-way analysis of variance are shown as follows: ns, not significant; * 0.01

$7<\mathrm{P} \leq 0.05 ; * * 0.001<\mathrm{P} \leq 0.01 ; * * * \mathrm{P} \leq 0.001$. 
1 Table 2. The dry mass of leaves, stems, roots and total biomass, and the root: shoot ratio in Populus cathayana females and males, as affected

2 cadmium stress, $\mathrm{N}$ deficiency and their combination.

\begin{tabular}{|c|c|c|c|c|c|c|}
\hline Sex & Treatment & Leaf mass (g) & Stem mass (g) & Root mass (g) & Total mass (g) & Root : Shoot \\
\hline \multirow[t]{4}{*}{ Female } & $+\mathrm{N}-\mathrm{Cd}$ (Control) & $17.01 \pm 0.93 \mathrm{a}$ & $16.76 \pm 0.77 \mathrm{~b}$ & $8.33 \pm 0.31 \mathrm{a}$ & $42.10 \pm 0.87 a$ & $0.247 \pm 0.014 c$ \\
\hline & $-\mathrm{N}-\mathrm{Cd}$ & $7.14 \pm 0.84 c$ & $4.66 \pm 1.06 \mathrm{de}$ & $3.52 \pm 0.42 \mathrm{e}$ & $16.29 \pm 1.62 d$ & $0.385 \pm 0.074 b$ \\
\hline & $+\mathbf{N}+\mathbf{C d}$ & $11.20 \pm 1.54 b$ & $13.95 \pm 1.04 \mathrm{c}$ & $6.11 \pm 0.58 b$ & $31.26 \pm 1.99 b$ & $0.243 \pm 0.022 c$ \\
\hline & $-\mathbf{N}+\mathbf{C d}$ & $4.04 \pm 0.94 d$ & $3.83 \pm 0.67 f$ & $4.49 \pm 0.63 \mathrm{~cd}$ & $11.39 \pm 1.45 \mathrm{e}$ & $0.510 \pm 0.087 \mathrm{a}$ \\
\hline \multirow[t]{4}{*}{ Male } & $+\mathrm{N}-\mathrm{Cd}$ (Control) & $8.11 \pm 0.24 c$ & $18.13 \pm 1.32 \mathrm{a}$ & $4.81 \pm 0.83 c$ & $31.05 \pm 1.52 b$ & $0.174 \pm 0.019 c$ \\
\hline & -N-Cd & $2.90 \pm 1.01 \mathrm{de}$ & $5.74 \pm 0.93 \mathrm{~d}$ & $2.37 \pm 0.093 f$ & $11.41 \pm 0.67 \mathrm{e}$ & $0.265 \pm 0.03 c$ \\
\hline & $+\mathbf{N}+\mathbf{C d}$ & $7.03 \pm 0.84 c$ & $14.88 \pm 0.45 c$ & $3.96 \pm 0.083 \mathrm{de}$ & $25.86 \pm 0.76 c$ & $0.181 \pm 0.0086 c$ \\
\hline & $-\mathrm{N}+\mathrm{Cd}$ & $2.06 \pm 0.26 \mathrm{~d}$ & $3.58 \pm 0.66 f$ & $2.34 \pm 0.37 f$ & $7.98 \pm 0.34 f$ & $0.424 \pm 0.11 b$ \\
\hline $\mathbf{P}_{\mathbf{s}}$ & & $* * *$ & $*$ & $* * *$ & $* * *$ & * \\
\hline $\mathbf{P}_{\text {cd }}$ & & $* * *$ & $* * *$ & $* * *$ & $* * *$ & $* *$ \\
\hline $\mathbf{P}_{\mathbf{n}}$ & & $* * *$ & $* * *$ & $* * *$ & $* * *$ & $* * *$ \\
\hline $\mathbf{P}_{\mathbf{s} \times \mathbf{c d}}$ & & $* * *$ & ns & $* *$ & $* * *$ & ns \\
\hline $\mathbf{P}_{\mathbf{s} \times \mathbf{n}}$ & & $* * *$ & ns & $* *$ & $* * *$ & ns \\
\hline $\mathbf{P}_{\mathbf{c d} \times \mathbf{n}}$ & & $*$ & $*$ & $* *$ & $* * *$ & ns \\
\hline $\mathbf{P}_{\mathbf{c d} \times \mathbf{m} \times \mathbf{n}}$ & & ns & ns & ns & $*$ & ns \\
\hline
\end{tabular}

3

$4 P_{s}$, sex effect; $P_{c d}, \mathrm{Cd}$ effect; $P_{n}, \mathrm{~N}$ effect; $P_{s \times c d}$, the interaction effect of sex and Cd. $P_{s \times n}$, the interaction effect of sex and N; $P_{c d \times n}$, the interaction

5 effect of $\mathrm{Cd}$ and $\mathrm{N} ; F_{s \times c d \times n}$, the interaction effect of sex, Cd and $\mathrm{N}$. Different letters on the bars indicate significant differences between the

6 treatments $(P<0.05$, Duncan's test). Values are expressed as means $\pm \mathrm{SE}(\mathrm{n}=6)$. The significance values of the three-way analysis of variance are

7 shown as follows: ns, not significant; * $0.01<\mathrm{P} \leq 0.05 ; * * 0.001<\mathrm{P} \leq 0.01 ; * * * \mathrm{P} \leq 0.001$. 
3 Figure 1 The concentrations of malondialdehyde (MDA), hydrogen peroxide $\left(\mathrm{H}_{2} \mathrm{O}_{2}\right)$

\section{Figure legends}

and superoxide radicals $\left(\mathrm{O}_{2}^{-}\right)$in the leaves and roots of Populus cathayana females and males, as affected by cadmium stress, $\mathrm{N}$ deficiency and their combination. $P_{s}$, sex effect; $P_{c d}, \mathrm{Cd}$ effect; $P_{n}, \mathrm{~N}$ effect; $P_{s \times c d}$, the interaction effect of sex and Cd. $P_{s \times n}$, the interaction effect of sex and N; $P_{c d \times n}$, the interaction effect of $\mathrm{Cd}$ and $\mathrm{N} ; F_{S \times c d \times n}$, the interaction effect of sex, $\mathrm{Cd}$ and N. Different letters on the bars indicate significant differences between the treatments. Values are expressed as means $\pm \operatorname{SD}(n=4)$. The significance values of the three-way analysis of variance are shown as follows: ns, not significant; * $0.01<\mathrm{P} \leq 0.05 ; * * 0.001<\mathrm{P} \leq 0.01 ; * * * \mathrm{P} \leq 0.001$.

Figure 2 The activities of superoxide dismutase (SOD), peroxidase (POD), catalase (CAT) and glutathione reductase (GR) in the leaves and roots of Populus cathayana females and males exposed to cadmium stress, $\mathrm{N}$ deficiency and their combination. $P_{s}$, sex effect; $P_{c d}, \mathrm{Cd}$ effect; $P_{n}, \mathrm{~N}$ effect; $P_{s \times c d}$, the interaction effect of sex and Cd. $P_{s \times n}$, the interaction effect of sex and N; $P_{c d \times n}$, the interaction effect of Cd and N; $F_{s \times c d \times n}$, the interaction effect of sex, $\mathrm{Cd}$ and N. Different letters on the bars indicate significant differences between the treatments. Values are expressed as means $\pm \operatorname{SD}(n=4)$. The significance values of the three-way analysis of variance are shown as follows: ns, not significant; $* 0.01<\mathrm{P} \leq 0.05 ; * * 0.001<\mathrm{P} \leq 0.01 ; * * * \mathrm{P} \leq 0.001$. 
1 Figure $3 \mathrm{Cd}$ accumulation in the leaves, roots, wood and bark of Populus cathayana

2 females and males exposed to cadmium stress, $\mathrm{N}$ deficiency and their combination. $P_{s}$,

3 sex effect; $P_{c d}, \mathrm{Cd}$ effect; $P_{n}, \mathrm{~N}$ effect; $P_{s \times c d}$, the interaction effect of sex and Cd. $P_{s \times n}$,

4 the interaction effect of sex and N; $P_{c d \times n}$, the interaction effect of $\mathrm{Cd}$ and $\mathrm{N} ; F_{s \times c d \times n}$, the

5 interaction effect of sex, Cd and N. Different letters on the bars indicate significant

6 differences between the treatments. Values are expressed as means $\pm \operatorname{SD}(n=4)$. The

7 significance values of the three-way analysis of variance are shown as follows: ns, not

$8 \quad$ significant; $* 0.01<\mathrm{P} \leq 0.05 ; * * 0.001<\mathrm{P} \leq 0.01 ; * * * \mathrm{P} \leq 0.001$.

Figure $4 \mathrm{Cd}$ distribution in the leaf vein cross-sections of Populus cathayana females and males exposed to cadmium stress, $\mathrm{N}$ deficiency and their combination as determined by energy-dispersive $\mathrm{x}$-ray analysis and scanning electron microscope imaging.

Figure $5 \mathrm{Cd}$ distribution in the leaf blade cross-sections of Populus cathayana females and males exposed to cadmium stress, $\mathrm{N}$ deficiency and their combination as determined by energy-dispersive x-ray analysis and scanning electron microscope imaging.

Figure $6 \mathrm{Cd}$ distribution in the root cross-sections of Populus cathayana females and males exposed to cadmium stress, $\mathrm{N}$ deficiency and their combination as determined by energy-dispersive $\mathrm{x}$-ray analysis and scanning electron microscope imaging. 
2 Figure $7 \mathrm{Cd}$ distributions in the root, leaf blade and vein cross-sections of Populus

3 cathayana females and males exposed to cadmium stress, $\mathrm{N}$ deficiency and their

4 combination as determined by energy-dispersive $\mathrm{x}$-ray analysis and scanning electron

5 microscope imaging.

7 Figure 8 FTIR spectra and the corresponding principle component analysis (PCA) plot

8 of leaves and roots of Populus cathayana females and males exposed to cadmium stress,

$9 \mathrm{~N}$ deficiency and their combination. The average spectrum of leaves and roots was plotted $(n=4)$. PCA was conducted with the data of selected peaks separately for leaves and roots (Supplementary Table 1).

Figure 9 Principal component analysis (PCA) plots of oxidants, antioxidants, photosynthesis parameters, pigments and biomass in the leaves and roots of Populus cathayana females and males exposed to cadmium stress, $\mathrm{N}$ deficiency and their combination. PCA was performed using the data presented in Tables 1-2 and Figs 1-2.

Figure 10 Effects of cadmium, nitrogen deficiency and their combination on the expression of heavy metal ATPase 2 and 4 (HMA2 and HMA4), metallothionein-like protein (MTP1), yellow stripe-like protein (YSL2), zinc transporter 2 and 6.2 (ZIP2 and ZIP6.2) genes in the roots of Populus cathayana females and males. Values are expressed as means \pm SD $(n=4)$. Different letters on the bars indicate significant 
1 differences between the treatments $(P<0.05$, Duncan's test $)$.

2

3 Figure 11 A schematic model for $\mathrm{Cd}$ accumulation, distribution and tolerance in

$4 \quad$ Populus cathayana females and males. CW, cell wall; PM, plasma membrane; ZIP2

5 and ZIP6.2, zinc/iron regulated transporter 2 and 6.2; ABCCs, ATP-binding cassette

6 transporter ; HMA2, P-type heavy metal ATPase 2; YSL2, yellow stripe-like2. 

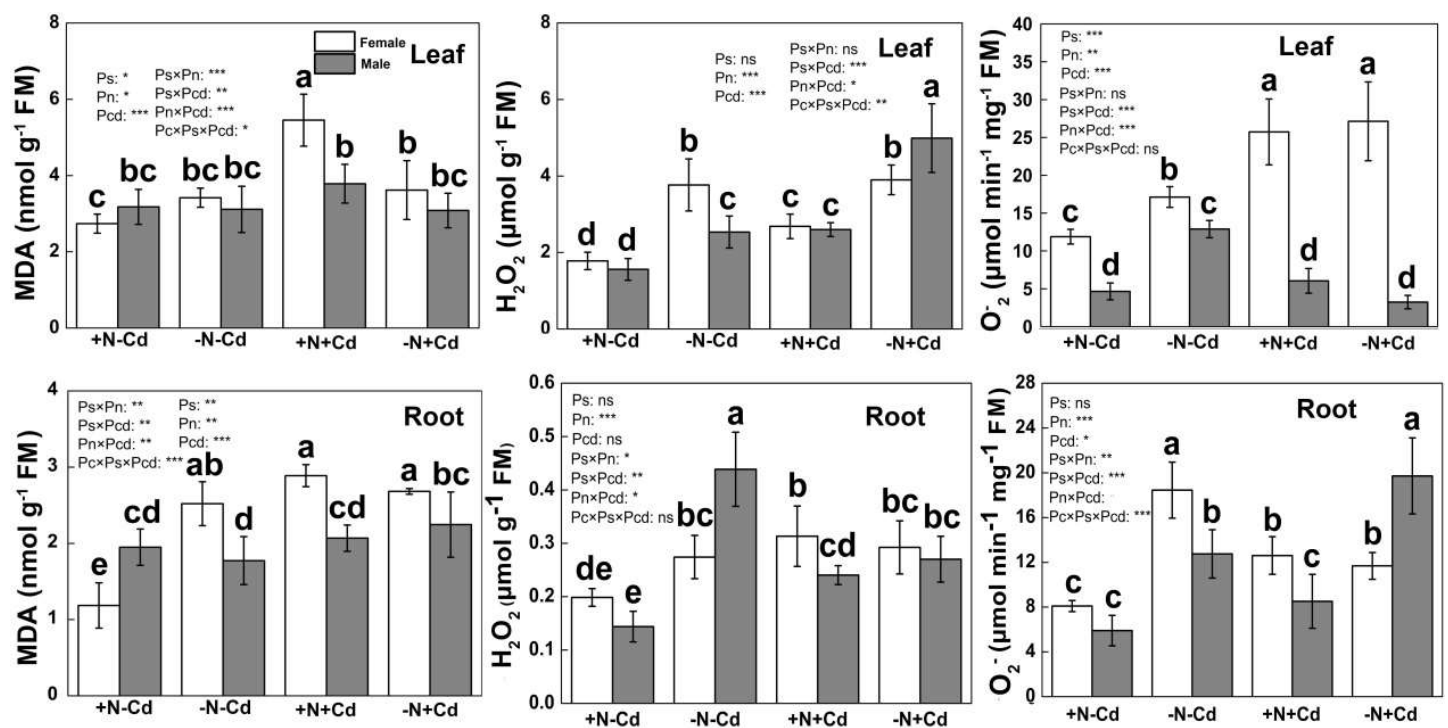

3 
Figure 2
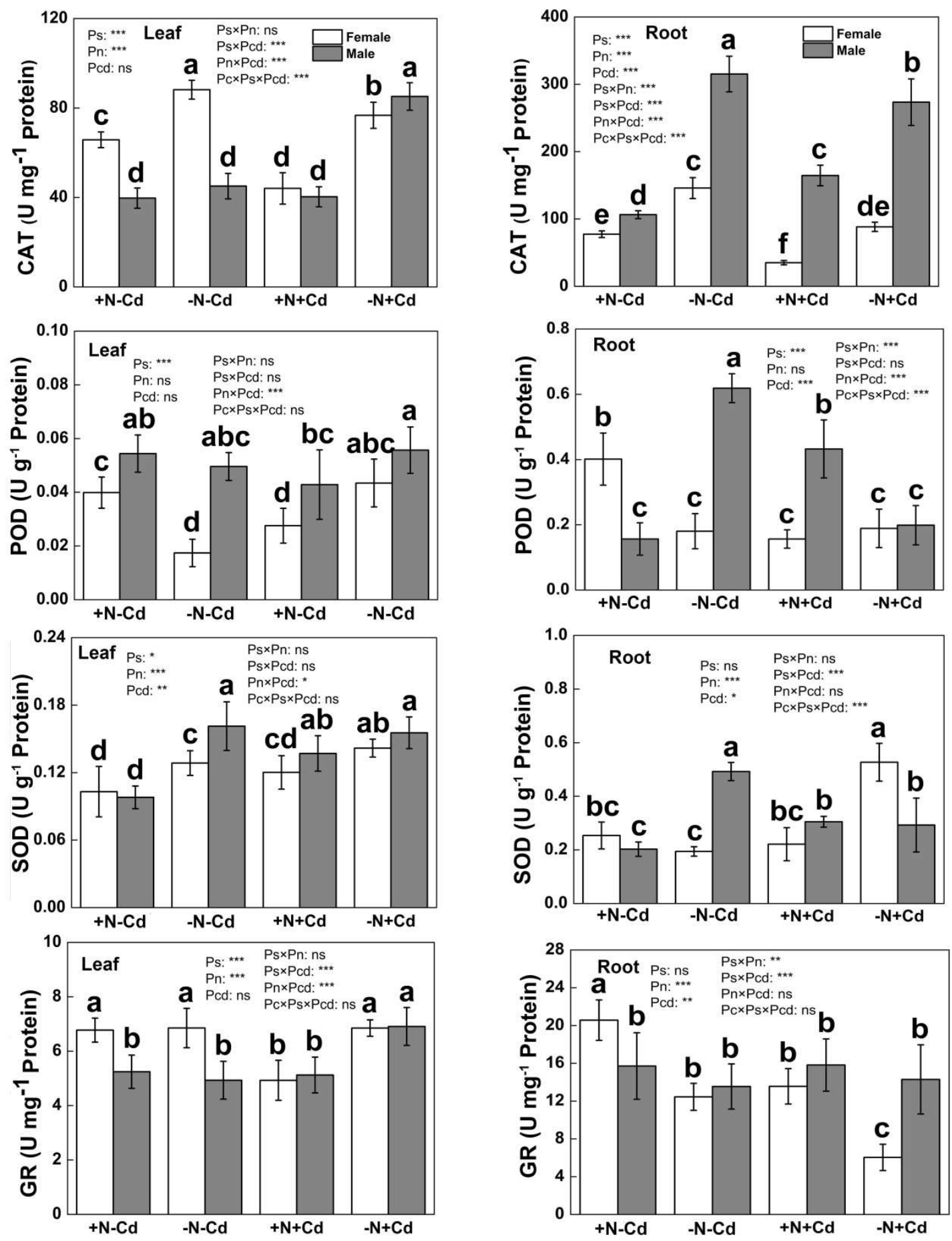
Figure 3
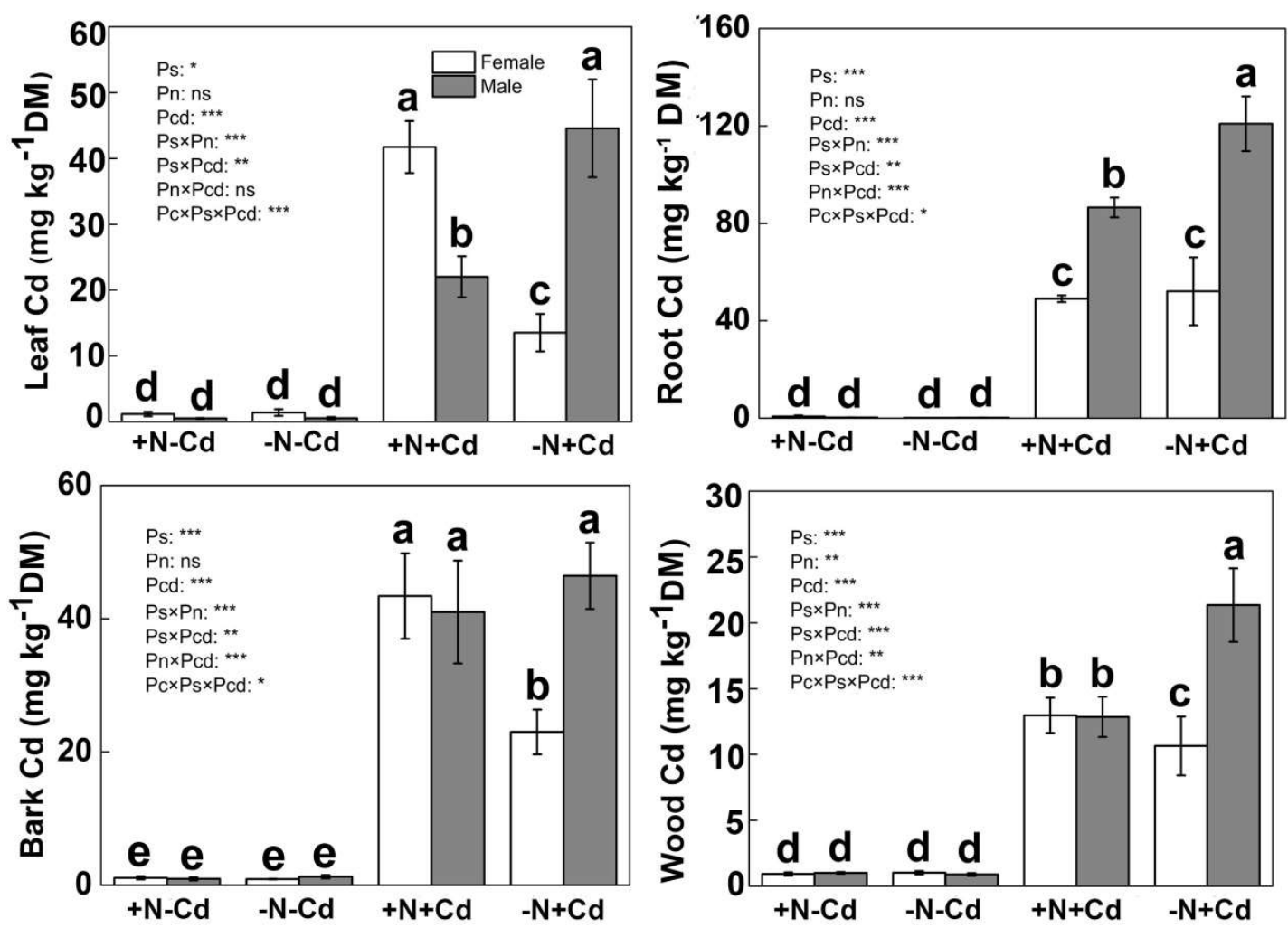

3

4

5

6

7

8 
Figure 4
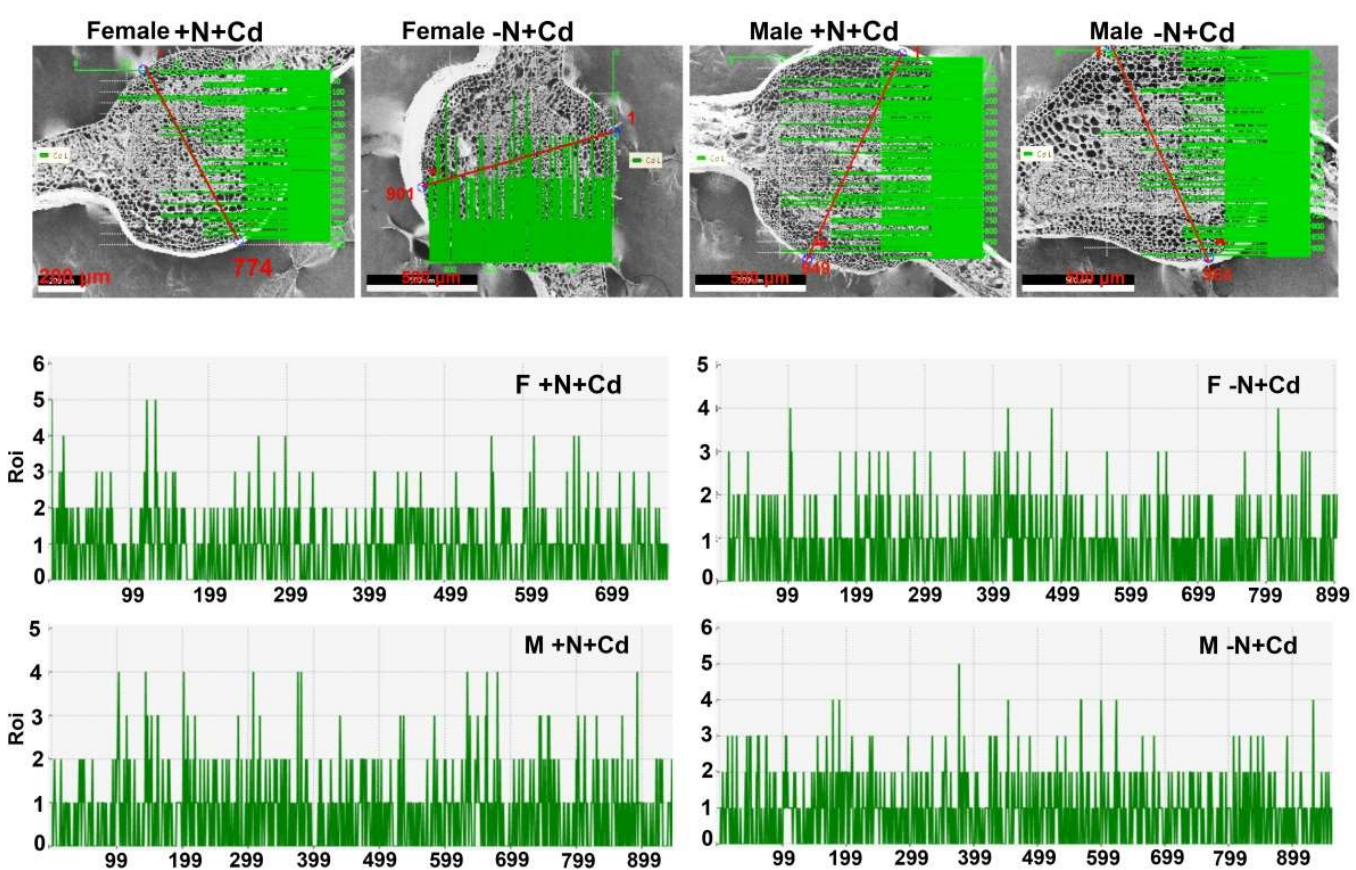

3

4

5

6

7

8

9

10

11

12

13

14 
Figure 5
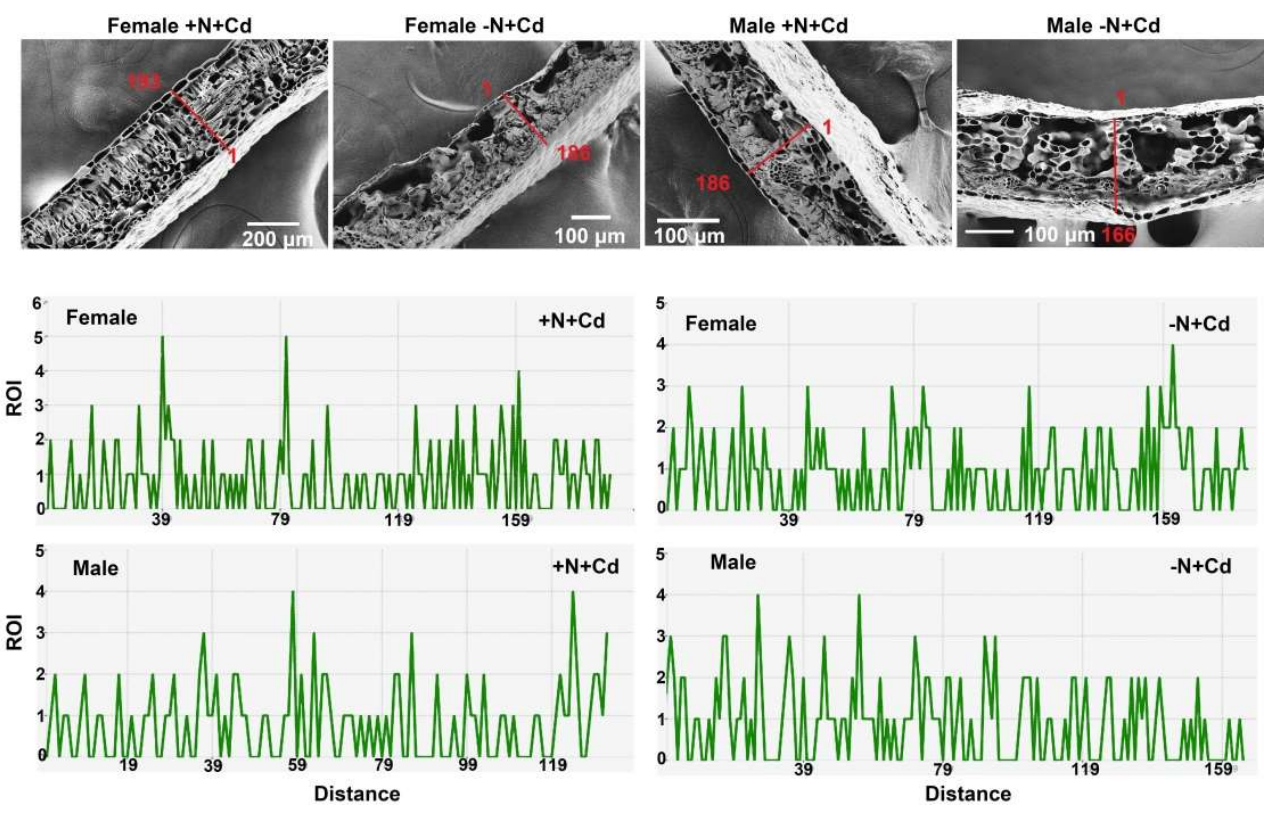

3

4

5

6

7

8

9

10 


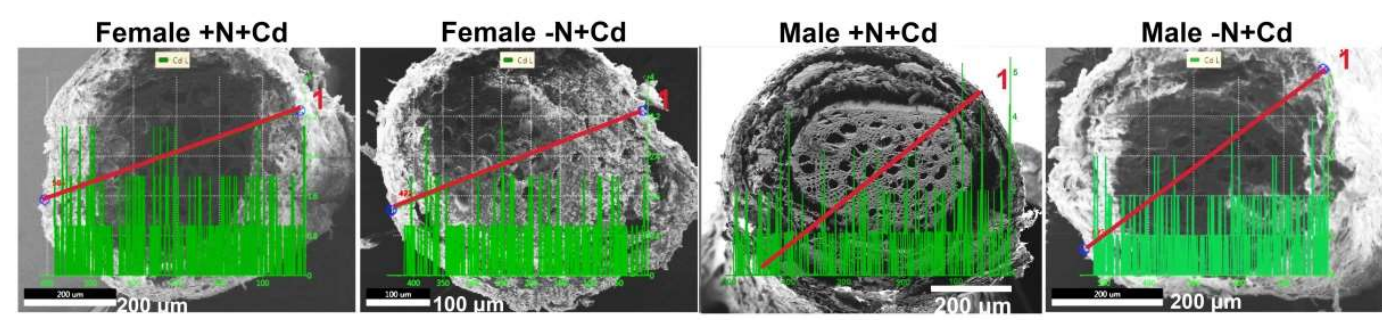

4 Female $+\mathrm{N}+\mathrm{Cd}$

4 Female $-\mathrm{N}+\mathrm{Cd}$

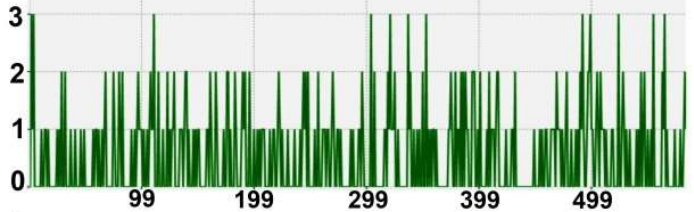

5 Male $+\mathrm{N}+\mathrm{Cd}$ 4. 3
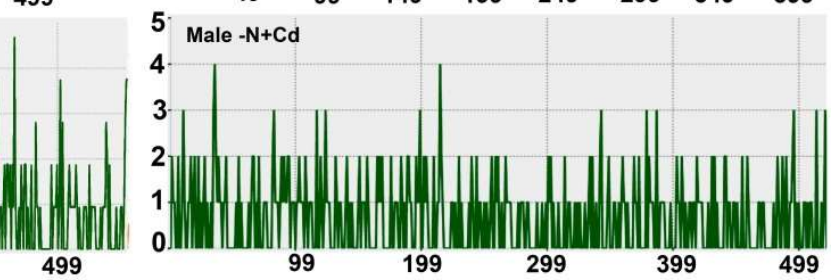

2 

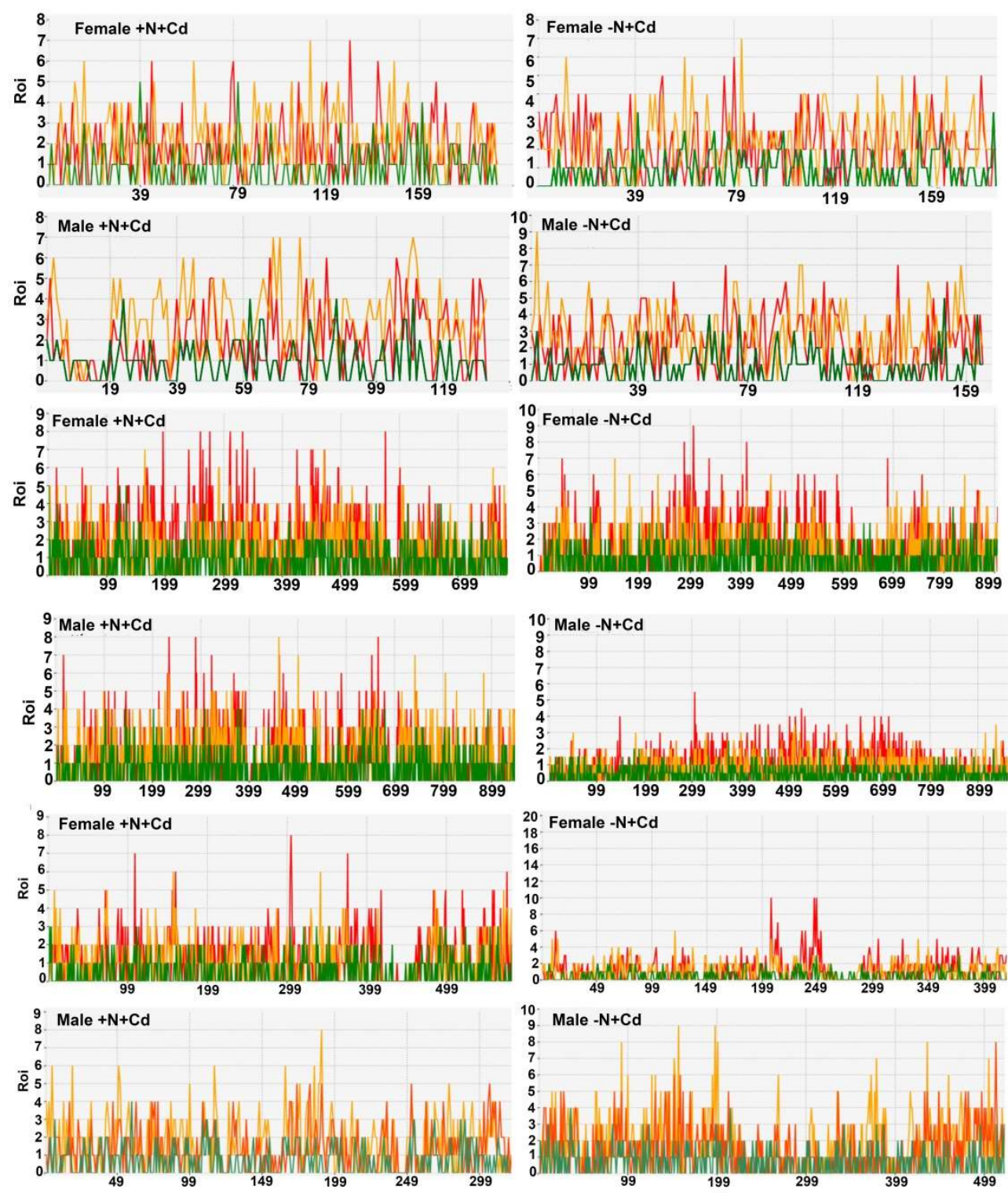
Figure 8
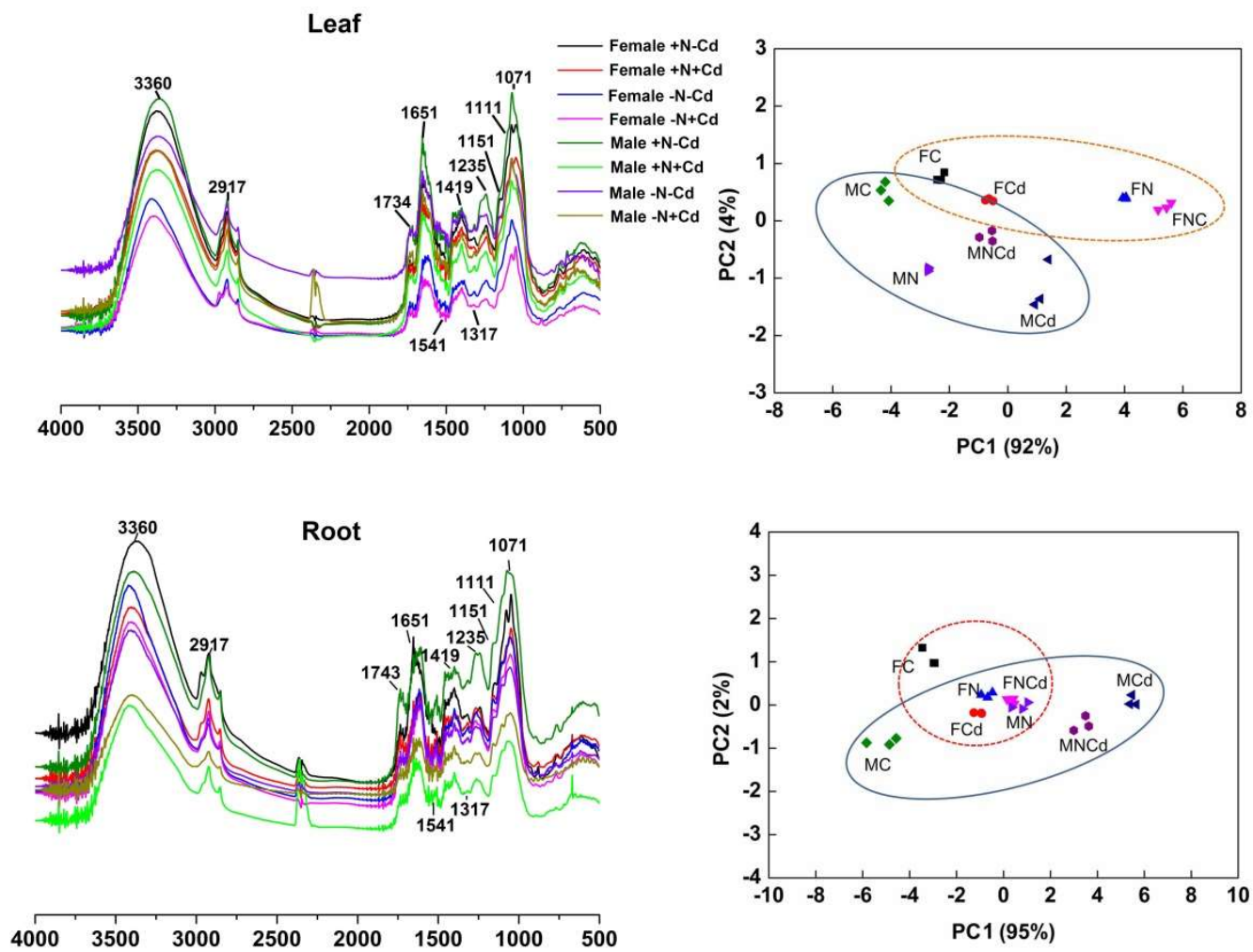

Wavenumber $\left(\mathrm{cm}^{-1}\right)$

3

4

5

6

7

8

9

10

11

12

13 
Figure 9

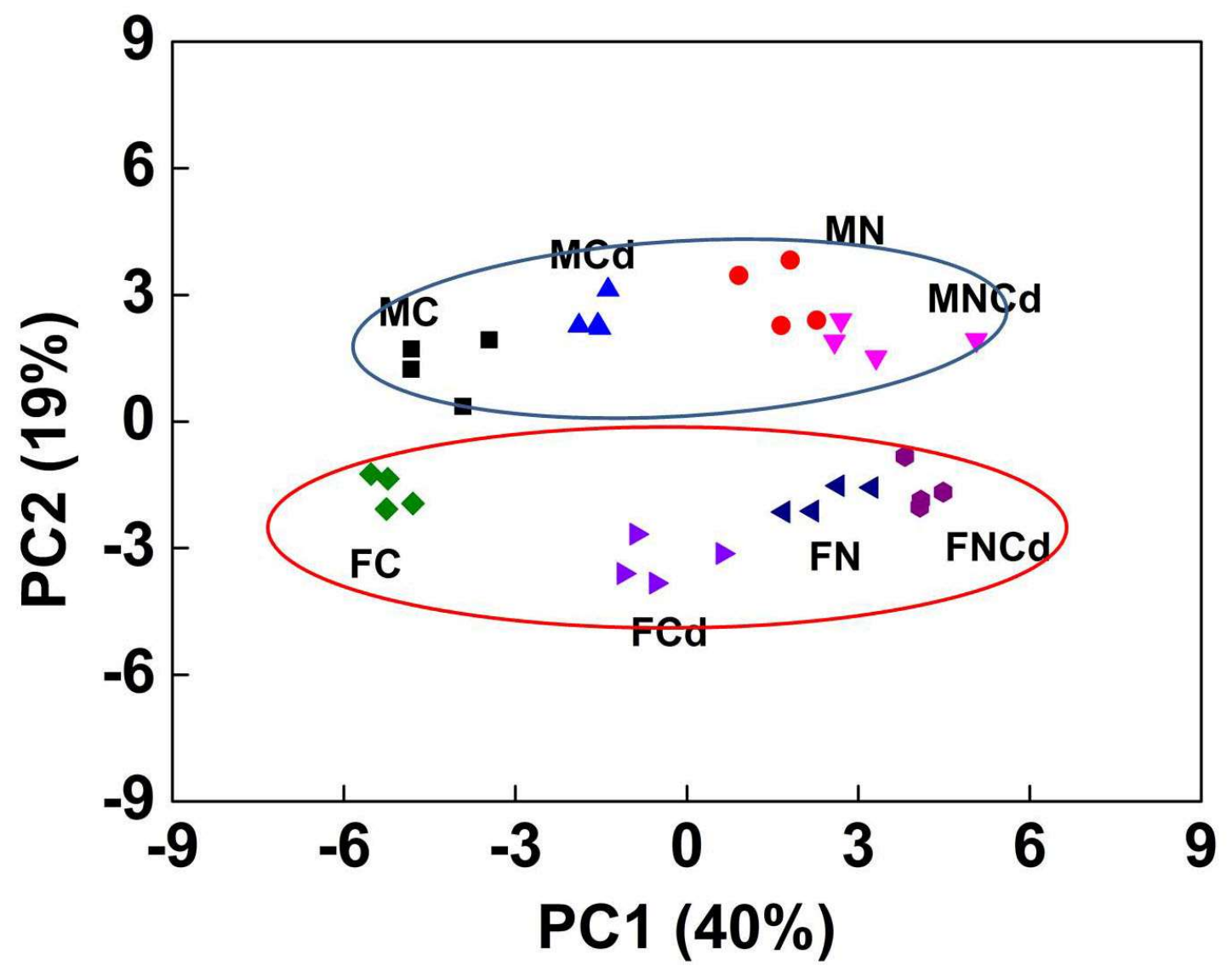

3

4

5

6

7

8

9 
Figure 10
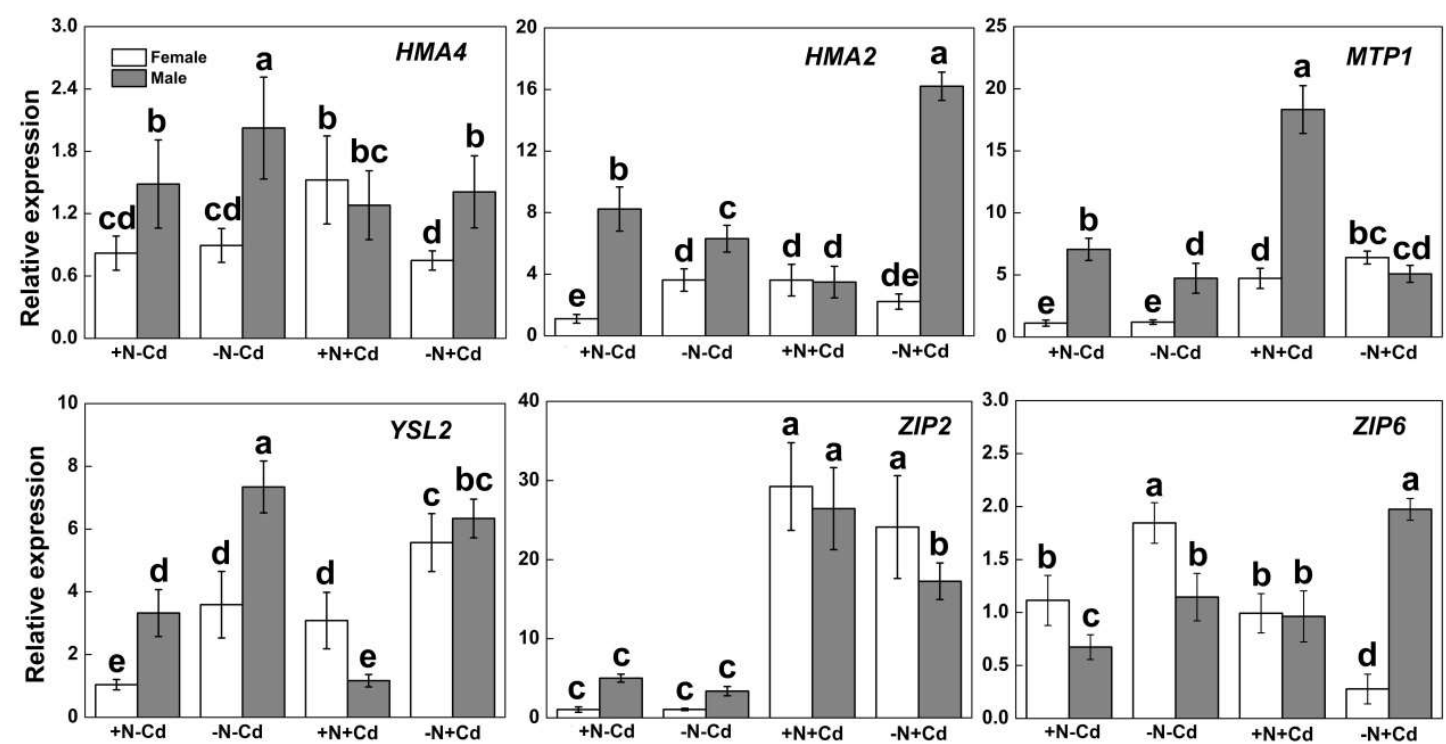


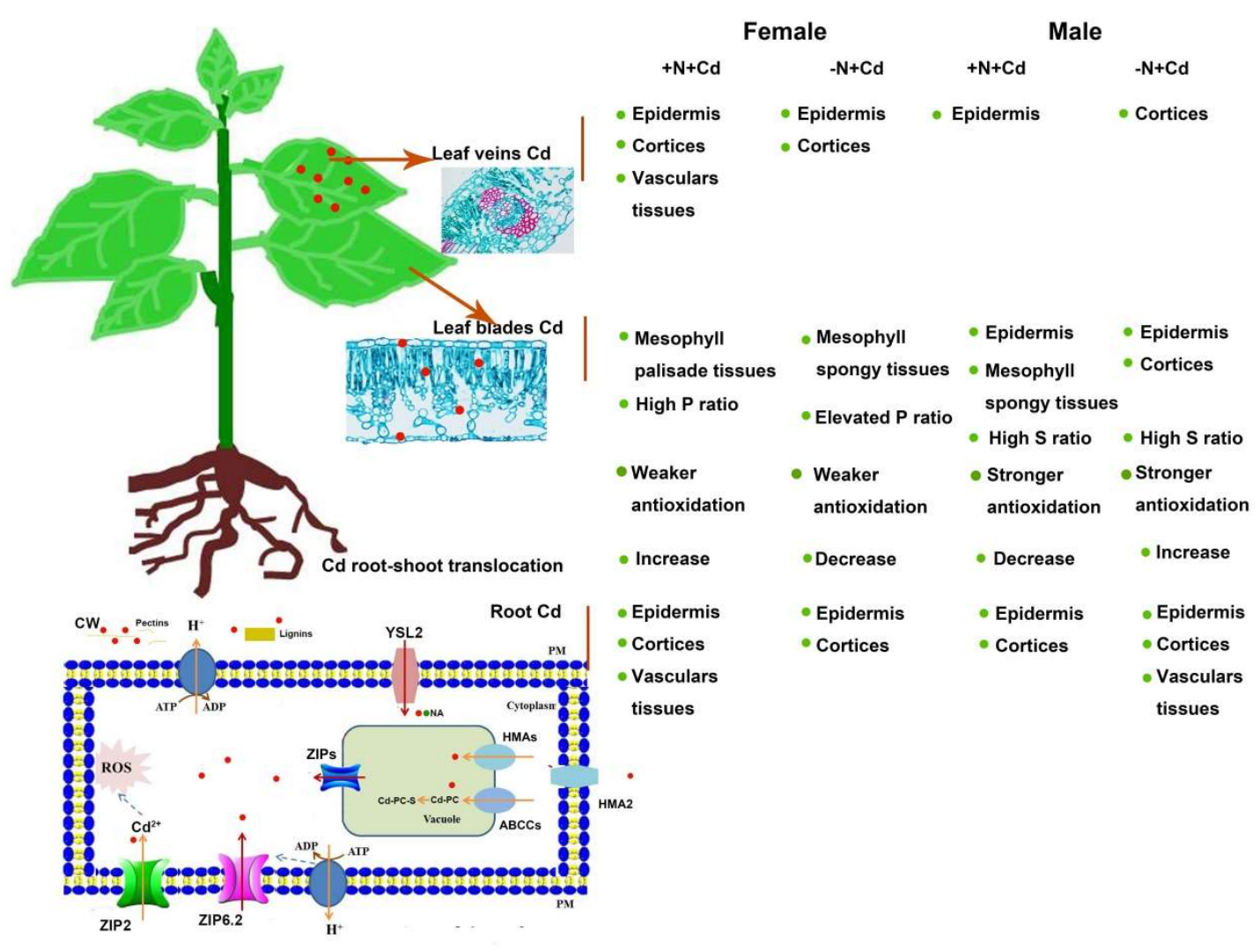

